\title{
Transthyretin and the brain re-visited: Is neuronal synthesis of transthyretin protective in Alzheimer's disease?
}

\author{
Xinyi Li and Joel N Buxbaum*
}

\begin{abstract}
Since the mid-1990's a trickle of publications from scattered independent laboratories have presented data suggesting that the systemic amyloid precursor transthyretin (TRR) could interact with the amyloidogenic $\beta$ amyloid (AB) peptide of Alzheimer's disease (AD). The notion that one amyloid precursor could actually inhibit amyloid fibril formation by another seemed quite far-fetched. Further it seemed clear that within the CNS, TTR was only produced in choroid plexus epithelial cells, not in neurons. The most enthusiastic of the authors proclaimed that TTR sequestered $A \beta$ in vivo resulting in a lowered TTR level in the cerebrospinal fluid (CSF) of AD patients and that the relationship was salutary. More circumspect investigators merely showed in vitro interaction between the two molecules. A single in vivo study in Caenorhabditis elegans suggested that wild type human TTR could suppress the abnormalities seen when $A \beta$ was expressed in the muscle cells of the worm. Subsequent studies in human $A \beta$ transgenic mice, including those from our laboratory, also suggested that the interaction reduced the $A \beta$ deposition phenotype. We have reviewed the literature analyzing the relationship including recent data examining potential mechanisms that could explain the effect. We have proposed a model which is consistent with most of the published data and current notions of $A D$ pathogenesis and can serve as a hypothesis which can be tested.
\end{abstract}

Keywords: Beta-amyloid precursor protein (AßPP, APP), Beta-amyloid (Aß), Alzheimer's disease (AD), Transthyretin (TTR), Amyloidosis, Protein homeostasis, Aggregation

\section{Introduction}

All amyloid fibrils are similar in appearance, displaying Congophilic, non-branching fibrils $7.5-10 \mathrm{~nm}$ in diameter. The twenty nine (thus far) identified human amyloid precursors [1] share no primary sequence and no common conformation although recent biophysical studies suggest the presence of conformationally/energetically similar repeat subunits which determine whether a given protein belongs to the "amylome" [2]. Further it has been suggested that while the precursors represent a variety of folded and unfolded native structures, a combination of primary structural features and level of expression determines the ordering of proteins along a proposed "edge of stability" under in vivo conditions, i.e. there are both qualitative and quantitative factors that

\footnotetext{
* Correspondence: jbux@scripps.edu

Department of Molecular and Experimental Medicine, The Scripps Research
} Institute, 10550 North Torrey Pines Rd., MEM-230, La Jolla, CA 92037, USA influence whether a protein will aggregate in vivo $[3,4]$. The frequency of many of the amyloidoses increases with aging but their deposition appears to be independent, i.e. each has its own anatomically predisposed site and pattern [5]. Thus, while there are reported instances of mixed precursor deposition, they are relatively uncommon, e.g. [6-9]. Nonetheless the commonality of structure that leads precursor proteins to form fibrils suggests that interaction could occur, perhaps accelerating fibril formation. The example of transthyretin (TTR) and $\beta$-amyloid $(A \beta)$ raises the question as to whether the effect may be, in truth, to reduce fibrillogenesis.

Wild type and mutant forms of TTR are the precursors in the systemic human diseases, Familial Amyloidotic Polyneuropathy (FAP), Familial Amyloidotic Cardiomyopathy (FAC) and Senile Systemic Amyloidosis (SSA) [10]. In contrast, Alzheimer's disease (AD) is a localized amyloid disease of the brain. AD and the TTR

\section{Ciomed Central}


amyloidoses share age dependence and are manifested as both autosomal dominant, mutation-related and sporadic (wild type protein associated) diseases. In the TTR amyloidoses the precursor is synthesized primarily by hepatocytes distant from the main sites of deposition in peripheral nerve and heart. However local synthesis and deposition can be seen in the eye, gut, kidney and choroid plexus. In $\mathrm{AD}$ the $\beta$-amyloid precursor protein $(\mathrm{A} \beta \mathrm{PP})$ is synthesized ubiquitously but deposition and tissue compromise are restricted to the brain and even more so to specific brain regions.

The first association of TTR with AD was the observation that cerebrospinal fluid (CSF) could inhibit $A \beta$ fibril formation in vitro [11]. TTR [12] was the third CSF protein found to interact with $A \beta$ after apolipoprotein $E$ (ApoE) [13] and ApoJ (or clusterin) [14]. It was hypothesized at that time that these three extracellular proteins could "sequester" $A \beta$, thereby preventing neuronal damage, although there was little evidence presented as to how or where such sequestration could take place. Perhaps "chaperone" in the sense of "protector" might have been a better term than "sequester", but the oxymoronic phrase "pathologic chaperone" had already been utilized to describe the co-deposition of ApoE in AD plaques [15].

Results of the early experiments supporting the association and suggesting that the interaction could be beneficial were suspect because of reservations concerning methodology. Further, the notion that an in vivo systemic amyloid precursor could have a salutary effect on the course of another, albeit local, form of amyloidosis, derived from a different precursor, taking place in a different, relatively closed anatomic compartment seemed counterintuitive. Lastly the published evidence that TTR was not a neuronal protein, but synthesized in choroid plexus epithelium made it seem unlikely that it could have much to do with the primarily neuronal degenerative process produced by aggregation of a protein produced in/by neurons [16].

We will review the relevant published papers that have contributed to our current knowledge regarding the relationship between TTR and AD. We will try to point out the inconsistencies that have cast doubt on the pathogenetic importance of the connections and we will present hypotheses that have been proposed to account for the interaction.

\section{Alzheimer's Disease}

The neuropathologic hallmarks of human AD include extracellular senile plaques consisting primarily of fibrils representing aggregated $A \beta$ peptides, intracellular neurofibrillary tangles composed of hyperphosphorylated microtubule-binding tau protein [17-19], and synaptic and neuronal loss particularly in the hippocampus and cortex, the regions associated with cognition and memory (reviewed in [20]). In addition inflammation (reviewed in $[21,22]$ ), oxidative damage (reviewed in [23-25]) and reactive gliosis [26] are evident in AD brains.

The precise molecular mechanisms responsible for the pathology of $\mathrm{AD}$ are still unclear although there is no lack of reasonable models. Since the original isolation and identification of $A \beta$ and $A \beta P P$, the weight of clinical and experimental evidence supports a major, if not primary role for $\mathrm{A} \beta$ in the development of $\mathrm{AD}$ (reviewed in [27-29]). Whether it is the ultimate source of the pathology is uncertain but the evidence for involvement of $\mathrm{A} \beta \mathrm{PP}$ in $\mathrm{AD}$ pathogenesis is convincing.

\section{A $\beta P P$ processing pathways}

A $\beta P$ P is a $695-770$ amino acid glycosylated membrane protein with a single hydrophobic transmembrane domain of 23 residues [30]. A large hydrophilic aminoectodomain of $A \beta P P$ is cleaved by $\alpha$ - or $\beta$-secretase to produce secreted A $\beta$ PP fragments, sAPP $\alpha$ or sAPP $\beta$, respectively [31] (see Figure 1). Alpha-secretase is a member of the ADAM (a disintegrin and metalloprotease) family of proteases anchored in the cell membrane [32-36], which includes ADAM9 [33], ADAM10 [35], ADAM17 (also known as tumour necrosis factor- $\alpha$ convertase, TACE) [37] and ADAM19 [36]. The sAPP $\alpha$ fragment appears to be involved in the development of the nervous system, promoting neurite outgrowth $[38,39]$, synaptogenesis $[40,41]$, enhancing memory formation [42], and providing neuro-protection against excitotoxic stimuli [43] and metabolic and oxidative insults [44] (For review see [45]).

Beta-secretase (BACE-1) is a predominantly $\beta$-site amyloid precursor protein-cleaving aspartyl-protease $[46,47]$. However the earlier notion that BACE- 1 is the only $\beta$-secretase activity protease in vivo $[48,49]$ has been challenged [50-52]. The BACE-1 cleavage product, sAPP $\beta$, does not have the same neuroprotective properties as SAPP $\alpha$. It has been recently shown that upon further cleavage, sAPP $\beta$ releases a $35 \mathrm{kDa}$ amino terminal fragment (N-APP), representing amino acids 1-286 of $A \beta P P$, that behaves as a ligand for neuronal death receptor 6 (DR6) [53]. That molecule has been hypothesized to be involved in pruning of synapses during development of both central and peripheral neurons [53]. The investigators suggested that aberrant activation of the "death signal" could play a role in AD pathogenesis but there is no published direct evidence for such an effect in $\mathrm{AD}$ (Figure 1).

Alpha and $\beta$ cleavages also yield small cytoplasmic carboxy-terminal fragments (CTF's), CTF83 and CTF99, respectively. In the so-called non-amyloidogenic pathway, CTF83 is digested by $\gamma$-secretase, a complex with 


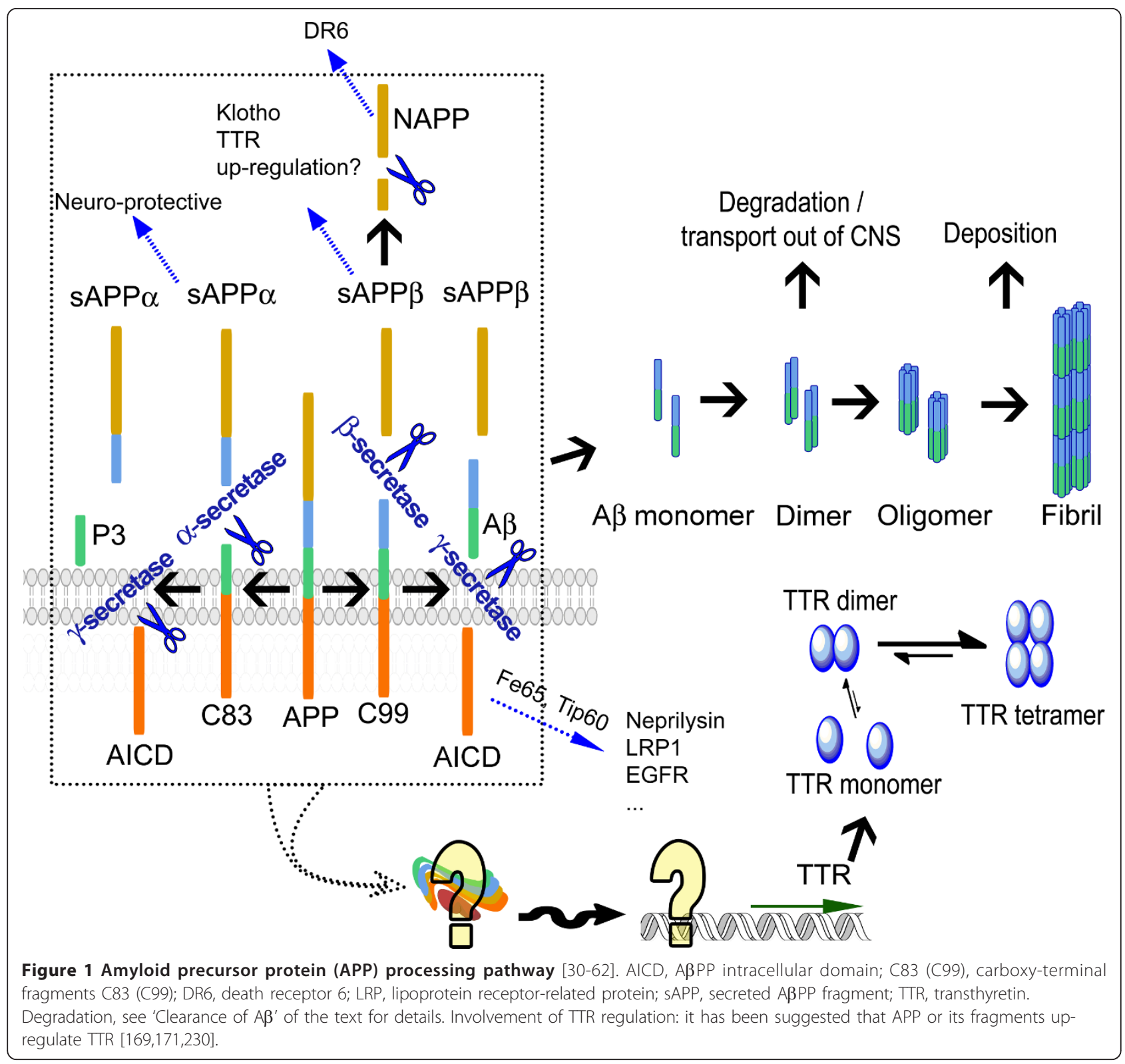

presenilin 1 at its catalytic core [54] (for $\gamma$-secretase reviews see [55-59]), releasing the APP intracellular domain (AICD) which may contribute to the toxicity of $\mathrm{AD}[60]$ and the extracellular p3 element with as yet no known function (reviewed in $[61,62])$. In the amyloidogenic pathway, CTF99 is cleaved by $\gamma$-secretase resulting in AICD and small peptides called $\mathrm{A} \beta$ ranging from 38 to 43 amino acids. $A \beta_{1-40}$ and $A \beta_{1-42}$ are the dominant forms in senile plaques $[63,64] . A \beta_{1-42}$ is more amyloidogenic and more prevalent in plaques than $A \beta_{1-40}$ [64] but the latter is more abundantly secreted by cultured cells $[65,66] . A \beta_{1-42}$ is generated in the endoplasmic reticulum/Golgi/intermediate compartment (ERGIC) $[67,68]$, while $A \beta_{1-40}$ is generated in trans-Golgi network
(TGN) [68]. The endosomal/lysosomal system also plays a role in generating $A \beta$ [69] (Figure 1).

\section{Clearance of $A \beta$}

The amyloidogenic peptides may be taken up by microglial and astrocytic endocytosis [70,71]; in the brain or by endothelial cells comprising the blood-brain barrier (BBB) [72]. They also form the neuropathologically diagnostic extracellular amorphous or fibrillar deposits (plaques). Some of the released peptides may enter the brain interstitial fluid (ISF) go to the CSF, then to the bloodstream, a pathway which may be responsible for $10 \%-15 \%$ of cerebral clearance of $A \beta$. The majority of clearance occurs via transport through the BBB [73]. 
Low-density lipoprotein receptor-related protein (LRP) regulates $A \beta$ clearance by carrying the peptide from brain to blood via transportation across the BBB [73] with the assistance of two other transporter ligands, apoE and $\alpha 2$-macroglobulin $(\alpha 2 \mathrm{M})$ (reviewed in $[74,75])$. The receptor for advanced glycation end products (RAGE) is the influx receptor for $A \beta[76,77]$.

Besides taking up soluble and fibrillar $A \beta$, microglia and astrocytes also secrete proteinases that degrade $A \beta$ extracellularly $[71,78]$. A $\beta$ can be degraded by a number of proteases including angiotensin converting enzyme (ACE) [79,80], Cathepsin B [81], endothelin converting enzymes (ECE) [82], glutamate carboxypeptidase II [83], matrix metalloproteinases (MMP-2/gelatinase A [84], MMP-9/gelatinase B $[85,86])$, plasmin $[87,88]$, neprilysin (also known as neutral endopeptidase 24.11 (NEP) and enkephalinase) [89,90] and insulin degrading enzyme (IDE, insulysin) [78,91]. Deficiency of neprilysin [92,93] and IDE [94] caused increased cerebral accumulation of endogenous $\mathrm{A} \beta$ in transgenic models of $\mathrm{AD}$ in vivo. Moreover, overexpression of neprilysin $[95,96]$ and IDE [96] reduced $A \beta$ levels and plaque burden in similar transgenic mice. Lipidated ApoE enhanced degradation of $A \beta$ by neprilysin [97].

\section{Amyloid hypothesis and alternatives}

With $A \beta$ as its focus, the current version of the "amyloid hypothesis" as the etiology of Alzheimer's disease proposes that "soluble oligomers" formed by $A \beta$ are the toxic agents rather than monomers or fibrils. The extracellular oligomers are proposed to induce inflammatory responses, oxidative stress etc. and ultimately cause neuronal spine and synaptic loss through an as yet unknown mechanism [98-101].

There is abundant evidence favoring an $A \beta$-centric hypothesis. Patients with Down's syndrome, caused by trisomy 21 , thus carrying a third copy of the A $\beta P P$ gene, uniformly develop AD-like pathology after age 40. The increased $A \beta P P$ gene dose results in elevated $A \beta$ level and early deposition of extracellular $A \beta$, neuritic plaques and neurofibrillary tangles [102-104]. In familial AD (FAD) mutations of presenilin 1 and 2 and $A \beta P P$ genes cause early onset FAD with increased amounts of $A \beta$ [105-108] or ratio of $A \beta_{1-42} / A \beta_{1-40}[109,110]$. In an early onset form of AD, the so-called Swedish double mutation $(\mathrm{K} 670 \mathrm{~N} / \mathrm{M} 671 \mathrm{~L})$, cleavage by $\beta$-secretase is enhanced with subsequent increased production of total A $\beta$ [111].

Transgenic mouse AD models have been created using genes encoding mutant forms of presenilin and $\mathrm{A} \beta \mathrm{PP}$ that have been identified in autosomal dominant forms of human AD. To some extent they all reproduce AD phenotypes, more closely resembling the early stages of the human disease than the globally symptomatic condition (see reviews [112-114]). The A $\beta$ PP models seem to require multiple copies of the mutant gene, creating a molecular environment more analogous to that in Down's syndrome than in sporadic human AD. It is not certain that the organismal response to multiple copies of a gene encoding a mutant protein is absolutely analogous to the disease produced by an aggregated fragment from two copies of a normal A $\beta$ PP gene. Nonetheless the molecular events and the pathologic sequellae are similar.

In human $\mathrm{AD}$ patients, the severity of pathology correlates best with the concentration of soluble $A \beta$ in the brain, not with that of the insoluble plaques, the morphologic hallmark of AD $[115,116]$. In brain-slices, dimers and trimers of $A \beta$ are synaptic toxins and oligomers inhibit long term potentiation [117-120]. Recently, it has been suggested that oligomeric $A \beta_{1-42}$ binds to $\operatorname{PrP}^{\mathrm{C}}$ and inhibits synaptic plasticity [121], however that observation has not been confirmed in all laboratories [122].

Other functional studies have indicated that the degree of dementia in $\mathrm{AD}$ is more highly correlated with the presence of neurofibrillary tangles than amyloid plaques $[123,124]$. However those studies antedated the analyses of soluble $A \beta$. Patients with mild cognitive impairment (MCI) who develop AD have lower levels of $\mathrm{A} \beta_{1-42}$, higher total tau ( $\mathrm{T}$-tau) protein, and tau phosphorylated at threonine $181\left(\mathrm{P}-\mathrm{tau}_{181}\right)$ in CSF than those who do not $[125,126]$. In CSF of AD patients, the decreased $A \beta_{1-42}$ and increased tau levels appear to be good biomarkers for some purposes [127-129].

In cell culture, in vitro synthesized $A \beta$ oligomers are toxic to a variety of cells [130]. When added to primary cultured murine neurons, the oligomers cause synaptic loss, calcium imbalance [131], disruption of mitochondria [132], with subsequent oxidative stress similar to that seen in brains of AD patients [133]. However most in vitro toxicity studies used synthetic $A \beta$ peptides and required higher $(\mu \mathrm{M})$ concentrations than those likely to be encountered in vivo. In addition the aggregationprone nature of $A \beta$ has made it difficult to identify the precise conformations of the toxic species. Despite these correlations, the relationship between $\mathrm{A} \beta$ cytotoxicity in tissue culture and the mechanism of neuronal loss in $\mathrm{AD}$ is still uncertain.

Hypotheses alternative to the amyloid cascade include a primary effect of ApoE on metabolism [134], membrane dysfunction caused by $\mathrm{A} \beta$ dimers [135], primary axonal transport dysfunction [136,137], oxidative stress related to aging, primary mitochondrial dysfunction or cerebrovascular disease [24] and a primary presenilin defect. These challenges to the amyloid cascade hypothesis have persisted (see reviews [138-142]), particularly since clinical trials of agents which targeted clearance of 
amyloid plaques or inhibition of $\gamma$-secretase have failed [143]. Nonetheless the hypothesis remains dominant with the failures being interpreted as being related to either inadequate specificity (in the case of $\gamma$-secretase inhibitors, resulting in off-target toxicity), unresponsive stage of disease, or neurovascular inflammation (as with the anti- $\mathrm{A} \beta$ antibodies) [144].

\section{Transthyretin (TTR)}

Unlike the circumstance in $\mathrm{AD}$ where $\mathrm{A} \beta \mathrm{PP}$ is produced and processed in neurons and $A \beta$ aggregates form primarily in the CNS, TTR, a $55 \mathrm{kDa}$ homotetrameric protein, causes disease by depositing as aggregates primarily at a distance from the major site of synthesis. The circulating protein is produced predominantly in the liver, which rarely displays evidence of aggregation or dysfunction. The TTR amyloidoses are prototypical systemic gain of toxic function disorders. The toxic species is comprised of aggregates formed from monomers which misfold after they dissociate from the homotetramer [145]. The most common form of TTR aggregation disease is senile systemic amyloidosis (SSA), caused by wild type TTR protein deposits in the heart, which increases in prevalence in the aged, with frequencies as high as $10-20 \%$ in the $9^{\text {th }}$ and $10^{\text {th }}$ decades, perhaps even higher in older groups $[146,147]$. Mutant TTR protein deposits in peripheral and autonomic nerves and heart are responsible for disease in familial amyloidotic polyneuropathy (FAP), and familial amyloidotic cardiomyopathy (FAC). More than 80 mutants have been reported to be responsible for autosomal dominant deposition disease [148]. CNS deposition has not been noted in FAP except in the choroid plexus and leptomeninges with rare unstable mutants (TTR's D18G, A25T, L12P) and in some cases of individuals carrying more common mutations, e.g. TTR V30M, which are primary sites of TTR synthesis [10]. The carriers of those mutations have a characteristic clinical CNS presentation, even though there does not appear to be actual neuronal involvement by the aggregates $[149,150]$.

TTR is a thyroid hormone (thyroxine (T4)) carrier and the only known plasma retinol (vitamin A) transporter, binding to retinol binding protein (RBP) charged with retinol. The binding sites for its normal ligands, T4 and RBP have been well defined [151-153]. Surprisingly, mice with their endogenous $t$ tr gene silenced have no apparent functional phenotype with respect to either thyroid function or vitamin A metabolism as long as vitamin A is supplied in the diet [154-156]. They have been shown to have a behavioral abnormality, the nature of which is currently under active investigation $[157,158]$ and have been reported by one laboratory to have a neuropeptide Y phenotype with obesity and hyperphagia [159]. They also appear to have a defect in peripheral nerve repair in response to injury and an abnormality in the proportion of proliferating to apoptotic cells in the supraventricular zone in the embryonic brain $[160,161]$.

In clinical situations in humans the serum TTR level $(0.08-0.45 \mathrm{mg} / \mathrm{ml})$ is used as a marker for malnutrition as well as inflammation, decreasing in both clinical settings [162]. Its serum level is decreased in patients with some tumors [163,164], although it is not clear whether the decrease is related to an inflammatory response or is an intrinsic property of the tumors.

TTR is encoded by a single copy of gene located on chromosome 18 in human and chromosome 4 in mouse. The gene contains four exons with the first exon encoding the leader sequence (reviewed in [10]). The gene is expressed in liver, kidney, pancreas, choroid plexus [165], retinal epithelium, leptomeningeal epithelium [166]. Despite the frequency of cardiac TTR deposition there does not appear to be either TTR gene transcription or TTR protein synthesis in the heart (Buxbaum unpublished). Several groups have shown material reactive with anti-TTR antibodies present in brain parenchyma indicating that the TTR mRNA is effectively translated [167-169]. However those observations could also be explained by neuronal endocytosis of TTR synthesized in choroid plexus epithelium [170,171]. More recent studies, using microarray analysis of RNA from carefully dissected regions of brains from multiple animals showed strain and regional variation in $t$ tr transcription in different areas of the brain parenchyma [172]. These results differ from those seen in earlier work, using primarily Northern blotting, which suggested that the choroid plexus was the only site of $t$ tr transcription in the brain and that the apparent neuronal expression was a function of contamination with choroid plexus or leptomeningeal epithelium [16,173-175]. The most recent results suggest that normally there is a very low level of neuronal TTR synthesis $[169,176]$ with substantial increase in particular pathologic states [169].

\section{Transthyretin in human AD}

Early immunopathologic studies, based on the premise that TTR might be the amyloid precursor in AD, gave conflicting results with respect to the presence of TTR in plaques in human AD brains [177,178]. More recent analyses found TTR co-localized in hippocampal plaques and vessels of AD patients [167,168]. Anti-TTR serum stained the majority of neuronal bodies in AD brains but only $10 \%$ of neurons in age-matched nondemented controls [169]. The latter finding may be responsible for the many reports of TTR synthesis only in the choroid plexus in the normal brain since the TTR signal from the choroid plexus, ependyma and leptomeninges is much stronger than that from normal neurons $[16,179]$. 
TTR, ApoE and ApoJ (clusterin) are major A $\beta$-binding proteins in human CSF [12-14]. The mean CSF TTR level has been reported to be decreased in several series of AD patients [180-184]. However not all investigators have found this to be true [185]. The significance of the decrease is not clear. It has been proposed, on the basis of the decrease, that TTR sequesters $A \beta$ but no site of sequestration has been identified. It is also possible that the CSF TTR concentration may be determined in part by neuronal TTR synthesis [169], particularly in AD (as well as choroid plexus production) and that the observed reduction is related to neuronal loss. Also plausible is the possibility that patients with $\mathrm{AD}$ have a genetic or acquired low CSF TTR level independent of A $\beta$ binding, which conceivably could put them at greater risk for AD. A recent analysis of TTR single nucleotide polymorphisms (SNPs) in the MIRAGE study of AD families has associated 5 TTR SNPs with hippocampal atrophy [186]. A prior single small study did not identify AD in carriers of amyloidogenic TTR mutations, but there is no a priori reason why such mutations would predispose to $\mathrm{A} \beta$ deposition [187].

Reduced CSF TTR levels have also been reported in patients with depression (although not in those who committed suicide), normal pressure hydrocephalus and most recently in amyotrophic lateral sclerosis (ALS) [188-190]. The variability of the finding has made it an unsuitable CSF marker for AD and made it more difficult to understand its role in AD pathogenesis.

An in vivo interaction between $A \beta / T T R$ was also noted in human kidneys [191], and in the muscle of a single patient with inclusion body myositis [192]. However its significance in these circumstances is unclear since the subjects did not have clinical AD.

It was hypothesized that TTR could inhibit $A \beta$ related toxicity by sequestration of $A \beta$ thus preventing $A \beta$ aggregation and fibril formation based on the observation that first identified TTR as an A $\beta$-binding protein in CSF [167]. In subsequent studies of the capacity of a series of recombinant mutant TTR's to inhibit A $\beta$ fibril formation at neutral $\mathrm{pH}$ in vitro was analyzed. The investigators found that the amount of Congo red binding material formed over a 24-36 hour period was reduced in the presence of many of the recombinant TTR's (at a 5:1 molar ratio of A $\beta: T T R$ ). However, the experiments suffered from the lack of non-TTR e.g. albumin, controls and the use of a relative measure of inhibitory capacity that was never quantified in terms of protein concentration. In addition the nature of the $\mathrm{A} \beta_{1-42}$ when it was added to the assay was not precisely defined. Given current knowledge regarding the propensity of $A \beta$ to aggregate on standing, it is not clear from the publications whether the different TTR's were actually seeing the same $A \beta$ conformers. Nonetheless in retrospect the observation that TTR bound $A \beta$ and inhibited fibril formation was correct, although the detailed results regarding the relative capacities of different variants are less likely to be valid. The hypothesis itself was attractive since TTR is abundant in Human CSF $(5-20 \mu \mathrm{g} / \mathrm{ml}$ or $0.1-0.36 \mu \mathrm{M})$ and serum (174-420 $\mu \mathrm{g} / \mathrm{ml}$ or $3-7 \mu \mathrm{M})[12,193]$; while $\mathrm{A} \beta$ concentration in CSF is relatively low (3 nM or less) [194,195]. However it inferred, as a second hypothesis, that the interaction would be responsible for lowering the CSF TTR concentration.

\section{Transthyretin in AD worm and mouse models}

The initial in vitro studies were followed by the intriguing report that in $C$. elegans, wild type human TTR co-expressed with $A \beta$ in body wall muscle cells under control of the same (unc 54) promoter rescued a phenotype of defective locomotion seen in animals expressing only A $\beta$ [196]. The significance of those data was not clear since no follow up studies were reported in the same system. However with the development of transgenic mouse models of $\mathrm{AD}$ it became possible to examine the phenomenon in a more disease-relevant experimental system.

In the transgenic mouse AD model Tg2576 in which the human APP Swedish mutation is expressed under the control of a hamster prion promoter and is associated with plaques, dystrophic neurites, vascular involvement and gliosis, analyses of transcription showed upregulation of ttr. TTR protein was immunochemically detected in neurons in the hippocampus and cerebral cortex, although neuronal-specific ttr transcripts were not assessed [171,197]. TTR immunoreactivity was seen in the same areas as the $A \beta$-staining plaques. Furthermore, injection of anti-TTR antibodies into one ventricle increased $A \beta$ deposition on the injected side relative to that seen in the contralateral cerebral hemisphere [168], suggesting that the reduction of functionally available TTR caused the increased AD-like pathology.

In later studies in the APP23 mouse model (Swedish mutation controlled by the Thy 1 promoter), hippocampal and cortical regions of brains from 15-month old mice showed neuronal staining for TTR and co-staining for $A \beta$ and TTR in the deposits. The blood vessels were also $A \beta$ and TTR positive [158]. Crossing the APP23 mice with a mouse strain over-expressing wild type human TTR under the control of its own promoter $\left(\mathrm{APP} 23 / \mathrm{hTTR}^{+}\right.$) normalized cognitive function and spatial learning as well as diminishing the neuropathologic changes and the amounts of $A \beta$ deposited in the animals bearing both constructs [158]. Moreover, APP23/ $\mathrm{m} t \mathrm{r}^{-/}$animals showed $\mathrm{A} \beta$ deposition in the hippocampus and/or cortex 3 months earlier than in the presence of the $t$ tr gene [158]. In animals sacrificed at 5.5 months 
of age the frequency and amount of $A \beta$ staining and extractable A $\beta$ in the brains of the APP23/mttr ${ }^{-/}$were greater than in the APP23/mttr ${ }^{+/+}$mice [158]. Another $\mathrm{AD}$ transgenic mouse model, the ceAPPswe/PS1 $\mathrm{E} 9$ mouse, hemizygous for a silenced $t$ tr allele, also showed earlier deposition than controls but not as early as in the homozygous knockouts in the APP23 mice [198], suggesting a gene dose effect.

Results of experiments examining the effects of silencing the $t$ tr gene on other models of AD have not been uniform. In contrast to the results suggesting a salutary effect of TTR in the Tg2576 AD model [171], other investigators reported that total and vascular $A \beta$ burdens in pooled 13-20 month-old Tg2576/TTR ${ }^{-1-}$ mouse brains were significantly increased compared to $\mathrm{Tg} 2576 /$ $T_{T R}{ }^{+/-}$mice [199]. The investigators saw no difference in the age of onset and progression between the two strains of mice. However those conclusions were based on examining only two mice from each group per month, which is probably not sufficient to be certain of the observations regarding the pace of development of disease reported in the APP23 mice. In addition homozygous Tg2576/TTR ${ }^{+/+}$control mice were not included in the study so there was no comparison between $\mathrm{ttr}^{+/+}$ and $t t^{-1-}$ animals. Similar studies were performed in TgCRND8 mice, a more aggressive AD model of $A \beta$ deposition in which plaques develop as early as 3 months. The magnitude of spatial memory deficits and $\mathrm{A} \beta$ plaque burden were not different in the hippocampi of 6-month-old TgCRND8/TTR ${ }^{+/}$, TgCRND8/TTR $R^{-/}$ and TgCRND8/TTR ${ }^{+/+}$mice [200]. In that model it might have been too late at 4 and 6 months of age to observe significant changes in the rate of development of disease due to the deletion of the ttr gene as suggested by the APP23 and ceAPPswe/PS1/AE9 experiments.

The variability in the results of the gene silencing experiments may be due to differences in the mouse strains studied. Alternatively, since it is clear that mice with two intact copies of the ttr gene still develop ADlike pathology, and there is considerable variation in the degree of pathology and behavioral abnormality seen from mouse to mouse in the same strain, it is difficult to get significant results without using relatively large numbers of animals of the same gender, precisely matched for age if one is trying to determine the pace of development of disease, rather than degree of pathology at the endpoint, which may be independent of the presence or absence of TTR. It is possible that examining the knockouts is observing the loss of a physiologic inhibitor/modulator of the pathogenetic process and more subject to mouse to mouse variation, while the over-expressed wild type hTTR transgene experiment is more analogous to a pharmacologic manipulation in which the agent is provided in sufficient quantities to overcome individual host differences. It might be useful to cross the $\mathrm{h} T T R$ over-expressing mice with animals bearing other $\mathrm{AD}$ mutants to be certain that the results seen in the APP23 strain were not peculiar to that strain combination.

\section{Transthyretin and $A \beta$ in vitro interaction}

In contrast to the results from in vivo mouse studies, results from in vitro experiments analyzing the interaction between TTR and A $\beta$ are more consistent, particularly in recent years when we have come to understand how to control the behavior of pro-amyloidogenic proteins in solution in vitro [201].

Schwarzman et al studied 47 recombinant TTR variants (see above). Most (except G42 and P55) bound to $A \beta$ and inhibited $A \beta$ aggregation in vitro [202]. But the interpretation of those experiments is subject to some reservations with respect to the experimental methodology (vide supra). Wild type human TTR binds to all forms of soluble $A \beta$, monomer, oligomer and fibrils [158,203-205]. TTR binds to $\mathrm{A} \beta$ better at $37^{\circ} \mathrm{C}$ than $25^{\circ}$ $C$ [158], binds to $A \beta$ aggregates better than $A \beta$ monomer $[158,205,206]$, and $A \beta_{1-42}$ better than $A \beta_{1-40}$ [158]. The binding is highly dependent on the quarternary structure of TTR [206]. It has been suggested that human monomeric TTR binds A $\beta$ better than the TTR tetramer. On the basis of tandem mass spectrometry analysis of a glutaraldehyde cross-linked TTR-A $\beta$ fragment, the $A \beta$ binding site appeared to be located in the A strand, in the inner $\beta$-sheet and EF helix of TTR [206]. These putative sites must be confirmed independently, using a different methodology. They do not correspond or encompass the sites proposed earlier based on structural modeling [12]. If the sites are correct then mutations in the potential binding residues should reduce affinity or abrogate binding completely.

The stoichiometry and the binding affinity of the $A \beta$ TTR interaction have been difficult to establish, perhaps because of the tendency of $A \beta$ to aggregate, so that its molecular mass at any moment of the interaction is probably heterogeneous. Using a tryptophan fluorescence quenching method, $\mathrm{K}_{\mathrm{s}}$ was estimated at $2300 \mathrm{M}^{-1}$ for TTR and A $\beta$ soluble species [205]. The authors noted that the $\mathrm{K}_{\mathrm{s}}$ could be underestimated by several orders of magnitude because the $A \beta$ monomer molecular weight was used in the estimation and it is likely that much of the bound $A \beta$ was heterogeneously oligomeric. Using a competition binding method with radioiodinated $A \beta_{1-42}$ (presumably a stronger binder than $\left.\mathrm{A} \beta_{1-40}\right)$ as the ligand the $\mathrm{Kd}$ was estimated to be $28 \mathrm{nM}$ [203]. However there is still lack of independent confirmation of this relatively strong interaction constant. In contrast to other laboratories the same investigators 
concluded that the binding between TTR and various A $\beta$ species is similar.

Nonetheless, it is now apparent, as originally suggested by Goldgaber and his colleague [12,202], that the interaction between TTR and $A \beta$ interferes with $A \beta$ aggregation in vitro. Using a variety of methods at least four other laboratories have now shown that TTR inhibits $A \beta$ fibril formation [158,203-205]. While it appears from some assays that TTR inhibits oligomer formation in others the mechanism of inhibition of fibril formation may be mediated via suppression of large aggregate formation ( $\mathrm{Li}$ and Buxbaum, unpublished). Two groups have clearly shown that monomeric TTR suppresses $A \beta$ fibril formation better than TTR tetramer (Li and Buxbaum, unpublished) [206]. The interaction between TTR and $A \beta$ species is apparently beneficial to cultured cells under $A \beta$ stress. TTR prevented accumulation of the $A \beta$ In cultured vascular smooth muscle cells [207]. In the human neuroblastoma cell line SK-N-BE, TTR inhibited ultrastructural changes characteristic of apoptosis [204]. Pre-incubation of A $\beta$ with TTR also suppressed caspase-3 activation in the undifferentiated human neuroblastoma SH-SY5Y cell line [203] and the cytotoxicity induced by $\mathrm{A} \beta$ oligomers on $\mathrm{SH}-\mathrm{SY} 5 \mathrm{Y}$ cells differentiated by retinoic acid treatment [169]. Moreover, TTR also inhibited cytotoxicity and the induction of reactive oxygen species (ROS) by $\mathrm{A} \beta$ species in cultured embryonic mouse neurons [169].

\section{Is the beneficial effect of transthyretin direct?}

While TTR binding to $A \beta$ appears to be well documented it is not clear how such binding impacts on $\mathrm{AD}$ in vivo. The notion of "sequestration" has been floated from the very beginning however, where or how the $A \beta$ is being "sequestered" is not apparent (see Figure 2 for hypothesis). It has also been suggested that TTR is a "cryptic protease" and cleaves A $\beta$ [208], with subsequent disaggregation of the fibrils [203]. The data supporting this hypothesis have not been confirmed by other laboratories, either with respect to disaggregation or proteolysis under physiologic conditions. The concentration of recombinant TTR $(13.6 \mu \mathrm{M})$ used to show cleavage of $A \beta$ [208] is almost twice the level found in the serum and 30 times higher than the concentration of TTR in CSF [12,193]. Since the concentration of TTR in the brain has not been determined these results have to be interpreted carefully.

If the soluble $A \beta$ oligomers or fibrils are the neurotoxic elements in AD patients or mouse models, the protective property of TTR can be a simple function of inhibiting aggregation and fibril formation by binding $\mathrm{A} \beta$ aggregates thus reducing their toxicity, as has been shown in vitro. TTR-A $\beta$ complexes have been co-immunoprecipitated from the cerebral cortices of APP23 mice as well as some human AD brains using anti-TTR sera, although the precise conformer of the bound $A \beta$ has not been established [169] (Figure 2).

In the APP23 AD mice over-expressing human TTR the amounts of SDS and formic acid extractable A $\beta$ species were markedly reduced [158]. Thus, in this model the suggestion that given its amyloidogenic property, TTR may bind to $A \beta$ and form large insoluble aggregates, thus protecting neurons from the toxicity induced by soluble oligomeric $A \beta$ species has no experimental support. It is also possible that TTR may bind to A PPP as well inhibiting the cleavage of the A $\beta P$ Py blocking at or close to $\alpha-, \beta$-, or $\gamma$-secretase docking sites, thus reducing the amount of $A \beta$ either by facilitating the non-amyloidogenic pathway (by helping $\alpha$-secretase docking) or by inhibiting the amyloidogenic pathway (preventing $\beta$ - or $\gamma$-secretase docking) [169]. This has been proposed to account for the salutary effect of the Bri2 transgene in a transgenic AD model [209]. It is also possible that TTR binds to the secretases or both the secretases and A $\beta P P$ (fragments/full-length) and blocks $A \beta$ production. This is another possible explanation for the markedly decreased $A \beta_{1-40 / 1-42}$ content in the presence of $A \beta P P$ in the cortex of the hTTR over-expressing APP23 mice [169] (Figure 2).

Since the evidence indicates that TTR can bind many forms of $A \beta$ it is also possible that TTR exerts its salutary effect on $\mathrm{AD}$, particularly when it is over-expressed in the APP23 mice, by enhancing the hypothesized "plasma sink" by which A $\beta$-binding molecules in the circulation shift the equilibrium of newly generated $A \beta$ from the brain, where the aggregates may be cytotoxic to the peripheral circulation, where they can be degraded. This has been proposed as an explanation for the effects of anti- $\mathrm{A} \beta$ antibodies, gelsolin and the ganglioside GM1 [210,211]. If that is the case it should be possible to isolate TTR-A $\beta$ complexes from the serum of the human TTR over-expressing APP23 mice.

\section{Is the beneficial effect of transthyretin indirect?}

Despite the evidence supporting a direct interaction between TTR and A $\beta$-related peptides, the TTR effect might be indirect. As an amyloidosis precursor, TTR could activate the unfolded protein (UPR), and other proteostatic responses thus inducing chaperone transcription, or activating stress related pathways, thus changing the protein homeostasis network to be more efficient in coping with $A \beta$ aggregation [212]. If this is the case, one would expect to find benefits from comparable over-expression of other amyloid precursor proteins. Wild type cystatin $\mathrm{C}$ and Bri2, other proteins in which mutations produce CNS amyloid deposition in humans, also inhibit $A \beta$ fibril formation [213-216] (Table 1). Gelsolin, another human amyloid precursor 


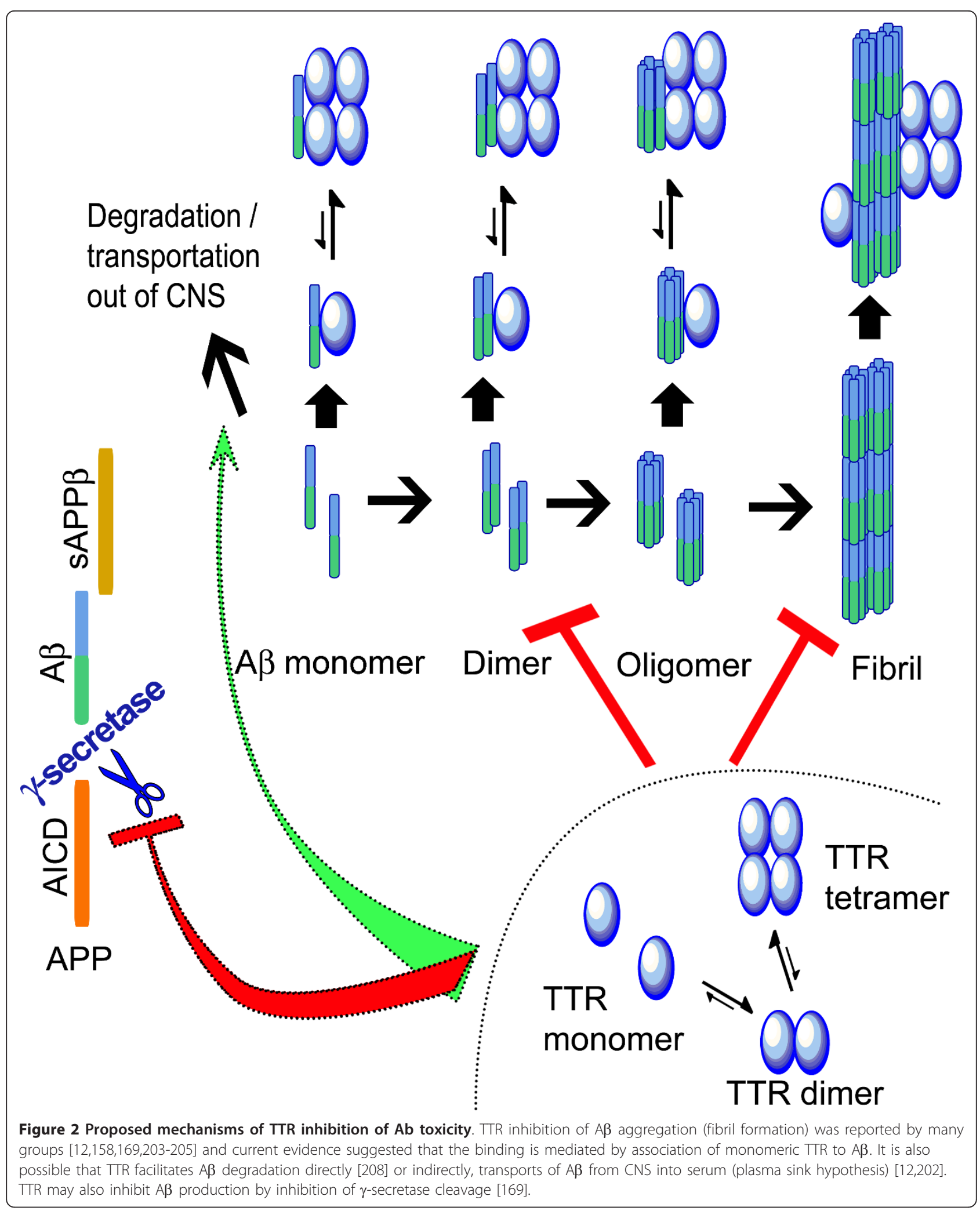


Table 1 Do Amyloid precursors "chaperone" A $\beta$ ?

\begin{tabular}{|c|c|c|c|c|c|}
\hline Protein & $\begin{array}{l}\text { Transgene } \\
\text { suppresses }\end{array}$ & $\begin{array}{l}\text { Knock-out } \\
\text { accelerates }\end{array}$ & Cytotoxic inhibition & In vitro interaction & In Human AD brains \\
\hline Transthyretin & + & + & + & + & + \\
\hline Bri2 & + & N.D. & N.D. & + & + \\
\hline Cystatin C & + & N.D. & N.D. & + & + \\
\hline Gelsolin & $+^{*}$ & N.D. & N.D. & + & + \\
\hline Neuroserpin & $t^{* *}$ & N.D. & + & + & + \\
\hline
\end{tabular}

N.D., Not Determined.

*Gelsolin only expressed in livers of transgenic animals.

**Neuroserpin experiments have only been done in transgenic drosophila.

binds $\mathrm{A} \beta$ [217] and ameliorates a transgenic AD model even when only expressed peripherally, a phenomenon more likely to reflect a "plasma sink" effect [218]. However each of these proteins binds $A \beta$ directly and their effects cannot be attributed exclusively to stimulation of protein homeostatic mechanisms.

Others have argued that the TTR effect in AD models depends upon its function as an RBP binding protein. Increased TTR could increase the amount of available retinoic acid, thus enhancing neuronal maintenance. Similarly the accelerating effect of the TTR knockout could depend on a relative lack of retinoids in the CNS which amplifies the toxic effect of $A \beta$. Retinoic acid inhibitors have been shown to compromise neuronal function in older rodents and retinoic acid has been found to enhance performance $[219,220]$. Thus it would be useful to determine if expressing a human AD gene on an RBP knockout background in the presence and absence of TTR would reveal a different phenotype from that seen when the APP23 construct is expressed in the absence of TTR alone. There are also suggestions that TTR may also be involved in AD through a vascular mechanism. In such a scenario TTR would cleave apolipoprotein A-I (ApoA-I), a constituent of HDL resulting in reduced cholesterol efflux and increased formation of amyloid fibrils [221].

Given the multiple functions of TTR (reviewed in [222]), it also possible that TTR enhances mechanisms that specifically degrade $A \beta$, or that it plays a currently unknown role in the maintenance of critical neuronal functions.

\section{Do Alzheimer's peptides regulate neuronal transthyretin expression?}

If TTR expression plays an important role in neuronal protection from $A \beta$ aggregation or processing or in the normal function of $A \beta P P$, it would seem appropriate for its expression to be regulated by the system involved in the generation of $A \beta$ or its related peptides. In hippocampal slices from Tg2576 AD mice TTR mRNA and protein were increased compared to WT mice $[158,168,171]$. The same was true in isolated cortex and hippocampus of the
APP23 mice. We can also infer that the same is true in human AD since there is little neuronal staining for TTR in non-demented human brains and extensive staining brains from AD patients as reported anecdotally by Goldgaber and Johnson and systematically examined in our laboratory (see above). Since primary cultured neurons derived from 14-16d embryonic mice of the same genotypes show markedly increased expression of the TTR gene, it is safe to say that the increased staining is due to increased synthesis rather than uptake of choroid plexus synthesized TTR [169].

It had previously been suggested that sAPP $\alpha$ might increase TTR transcription, although at that time TTR mRNA had not been demonstrated in neurons [223]. In more recent studies it has been reported that the AICD fragment regulates transcription of other genes through activating Fe65 and the chromatin-remodeling factor Tip60 [224-227]. The genes regulated by AICD include neprilysin, the neutral endopeptidase with $A \beta$-degrading activity (vide supra) [225]; lipoprotein receptor LRP1 which is related to cholesterol metabolism and $A \beta$ transport [228]; EGF receptor, whose promoter is bound by AICD and negatively regulated [229] etc. Most recently it has been suggested that the TTR and Klotho genes are specific downstream targets of sAPP $\beta$ [230]. TTR and Klotho expression are decreased in loss-offunction states but increased in gain-of-function states using transcriptional profiling [230] (Figure 1).

When mice are exposed to environmental "enrichment", both the steady-state levels of $A \beta$ peptides and $\mathrm{A} \beta$ deposition in brains of APPswe/PS1 $\triangle \mathrm{E} 9$ are significantly reduced, and $t$ tr is one of the genes up-regulated [231]. Similarly administration of Gingko biloba and a number of unsaturated fatty acids to rodents have been reported to increase TTR mRNA abundance in cortical neurons as measured by microarray analysis [232-234]. Some of these compounds have had favorable effects in transgenic models of human AD $[235,236]$. However large studies of at least one of these in human AD patients have failed to show any benefit [237]. Perhaps this is just an example of "too little too late" rather than a conceptual error. 
Summary: Transthyretin, aging and Alzheimer's disease Over-expression of human TTR suppresses the AD phenotype in a well validated model of human AD. Silencing the endogenous $t$ tr gene appears to accelerate the disease but those results are less consistent. The majority of cortical and hippocampal neurons in human AD brains contain TTR protein as do the neurons in several murine AD models. The increased neuronal TTR is the result of increased transcription. In vitro interaction between recombinant TTR and synthetic A $\beta$ has been demonstrated in multiple laboratories with the interaction reducing both fibril formation and $A \beta$-induced cytotoxicity in tissue culture. The interaction has now been shown to occur in vivo in both a murine model and in some human AD brains. Further it appears that TTR transcription may be directly influenced by the $A \beta$ precursor. Thus wherever $A \beta$ peptides are produced, i.e. intracellularly in neurons or secreted into the cerebral interstitial space, TTR is available, either on the basis of neuronal (intracellular) or choroid plexus production and secretion. If, as suggested by the in vitro studies, the TTR monomer is critical for binding intracellular $A \beta$, it is likely that newly synthesized peptide rather than dissociated tetramer is the source. Hence we would expect to find $A \beta_{1-40 / 42}$ and TTR monomer in the same cellular compartment.

In the face of these data suggesting a role for TTR in suppressing the molecular events responsible for clinical $\mathrm{AD}$, one must conclude that with time the amount of pathogenic $A \beta$ peptide production exceeds the neuron's capacity to neutralize it. This neutralizing capacity may be represented by the conventional protein homeostasis network (including the unfolded protein response, heat shock induced chaperones and their co-chaperones, the proteasome ubiquitin system and autophagic responses) [212]. It now appears that in this setting TTR may also comprise part of that network. There are considerable data suggesting that these mechanisms decline with aging. A relative deficiency of any of them may render the normal processes that deal with $A \beta$ or its aggregates unable to compensate for a constant (or increased) aggregate load thus initiating disease. Such a scenario could certainly account for the findings in the over-production models of AD, whether it also applies in sporadic disease is a subject of speculation and further investigation. For the moment any such studies cannot ignore the role of TTR since hippocampal and cortical neurons from human $\mathrm{AD}$ and mouse $\mathrm{AD}$ model brains seem to increase its production.

\section{Epilogue: Is transthyretin the only one?}

$\mathrm{A} \beta$ amyloid formation, like all amyloidogenesis involves homotypic interactions that result in aggregation with subsequent toxic oligomer and fibril formation.
Intracellular aggregation is suppressed by heterotypic interactions between the amyloidogenic precursors and elements of the chaperone system, allowing refolding or transport in the soluble state to either the secretory pathway or to the cellular degradative machinery. In the vast neuropathologic literature describing $\mathrm{AD}$, a number of molecules have been found co-localized in the $A \beta$ deposits. Similarly in the hundreds of publications utilizing the murine $\mathrm{A} \beta \mathrm{PP}$ transgenic mice as $\mathrm{AD}$ models, there are reports of many manipulations that enhance or diminish the AD phenotype. We have presented a detailed analysis of the evidence suggesting that wild type TTR, a systemic amyloid precursor, can suppress $\mathrm{A} \beta$ aggregation in vitro and in vivo and ameliorate its pathologic effects in a well-validated transgenic mouse model of human AD. In the AD model literature we noted that reports indicating that wild type forms of other proteins rendered amyloidogenic by autosomal dominant mutations, e.g. Bri2 [215], cystatin C $[213,214]$, gelsolin $[217,218,238]$, and perhaps neuroserpin [239] (mutations result in non-amyloid neuropathologic aggregation), seem to be over-represented as a class. They appear to have the capacity to interact with $\mathrm{A} \beta$ and in some instances suppress the AD phenotypes in transgenic mouse models (see Table 1). It is possible that the same structural features that predispose these proteins to undergo the homotypic interactions that result in aggregation when affected by a particular structural change as a consequence of mutation, allow the wild type conformers to interact heterotypically to prevent aggregation of similarly susceptible client proteins, in this case $A \beta$. Whether the phenomenon represents therapeutically exploitable physiology remains to be seen.

\section{Acknowledgements}

The author's work cited in this review was supported by NIH grant AG R01 030027 (JNB). NIH AG18440, AG5131, AG22074, AG11385, AG10435, NS057096 (Eliezer Masliah); WM Keck Foundation (JNB; XL)

\section{Authors' contributions}

$\mathrm{XL}$ and JNB wrote the manuscript. Both authors read and approved the final manuscript.

\section{Competing interests}

The authors declare that they have no competing interests.

Received: 17 September 2011 Accepted: 23 November 2011 Published: 23 November 2011

\section{References}

1. Sipe JD, Benson MD, Buxbaum JN, Ikeda S, Merlini G, Saraiva MJ, Westermark P: Amyloid fibril protein nomenclature: 2010 recommendations from the nomenclature committee of the International Society of Amyloidosis. Amyloid 2010, 17:101-104.

2. Goldschmidt L, Teng PK, Riek R, Eisenberg D: Identifying the amylome, proteins capable of forming amyloid-like fibrils. Proc Natl Acad Sci USA 2010, 107:3487-3492 
3. Tartaglia GG, Pechmann S, Dobson CM, Vendruscolo M: Life on the edge: a link between gene expression levels and aggregation rates of human proteins. Trends Biochem Sci 2007, 32:204-206.

4. Sekijima Y, Wiseman RL, Matteson J, Hammarstrom P, Miller SR, Sawkar AR, Balch WE, Kelly JW: The biological and chemical basis for tissue-selective amyloid disease. Cell 2005, 121:73-85.

5. Wright JR, Calkins E, Breen WJ, Stolte G, Schultz RT: Relationship of amyloid to aging. Review of the literature and systematic study of 83 patients derived rom a general hospital population. Medicine 1969, 48:39-60.

6. Bergstrom J, Murphy C, Eulitz M, Weiss DT, Westermark GT, Solomon A, Westermark P: Codeposition of apolipoprotein A-IV and transthyretin in senile systemic (ATTR) amyloidosis. Biochem Biophys Res Commun 2001, 285:903-908

7. Brancaccio D, Ghiggeri GM, Braidotti P, Garberi A, Gallieni M, Bellotti V, Zoni U, Gusmano R, Coggi G: Deposition of kappa and lambda light chains in amyloid filaments of dialysis-related amyloidosis. J Am SOC Nephrol 1995, 6:1262-1270.

8. de Sousa MM, Vital C, Ostler D, Fernandes R, Pouget-Abadie J, Carles D, Saraiva MJ: Apolipoprotein Al and transthyretin as components of amyloid fibrils in a kindred with apoAI Leu178His amyloidosis. Am J Pathol 2000, 156:1911-1917.

9. Takahashi M, Hoshii Y, Kawano H, Gondo T, Ishihara T, Isobe T: Ultrastructural evidence for colocalization of kappa light chain- and beta 2-microglobulin-derived amyloids using double labelling immunogold electron microscopy. Virchows Arch 1996, 429:383-388.

10. Buxbaum JN: Transthyretin and the Transthyretin Amyloidoses. In Protein Misfolding, Aggregation, and Conformational Diseases. Edited by: Uversky VN, Fink A. Santa Cruz, California: Springer; 2007:259-283.

11. Wisniewski T, Castano E, Ghiso J, Frangione B: Cerebrospinal fluid inhibits Alzheimer beta-amyloid fibril formation in vitro. Ann Neurol 1993, 34:631-633.

12. Schwarzman AL, Gregori L, Vitek MP, Lyubski S, Strittmatter WJ, Enghilde JJ, Bhasin R, Silverman J, Weisgraber KH, Coyle PK: Transthyretin sequesters amyloid beta protein and prevents amyloid formation. Proc Natl Acad Sci USA 1994, 91:8368-8372.

13. Strittmatter WJ, Weisgraber KH, Huang DY, Dong LM, Salvesen GS, PericakVance M, Schmechel D, Saunders AM, Goldgaber D, Roses AD: Binding of human apolipoprotein $\mathrm{E}$ to synthetic amyloid beta peptide: isoformspecific effects and implications for late-onset Alzheimer disease. Proc Natl Acad Sci USA 1993, 90:8098-8102.

14. Ghiso J, Matsubara E, Koudinov A, Choi-Miura NH, Tomita M, Wisniewski T, Frangione B: The cerebrospinal-fluid soluble form of Alzheimer's amyloid beta is complexed to SP-40,40 (apolipoprotein J), an inhibitor of the complement membrane-attack complex. Biochem J 1993, 293(Pt 1):27-30.

15. Wisniewski T, Frangione B: Apolipoprotein E: a pathological chaperone protein in patients with cerebral and systemic amyloid. Neurosci Lett 1992, 135:235-238

16. Sousa JC, Cardoso I, Marques F, Saraiva MJ, Palha JA: Transthyretin and Alzheimer's disease: where in the brain? Neurobiol Aging 2007, 28:713-718

17. Kosik KS, Joachim CL, Selkoe DJ: Microtubule-associated protein tau (tau) is a major antigenic component of paired helical filaments in Alzheimer disease. Proc Natl Acad Sci USA 1986, 83:4044-4048.

18. Goedert M, Spillantini MG, Cairns NJ, Crowther RA: Tau proteins of alzheimer paired helical filaments: Abnormal phosphorylation of all six brain isoforms. Neuron 1992, 8:159-168.

19. Ihara Y, Nukina N, Miura R, Ogawara M: Phosphorylated Tau protein is integrated into paired helical filaments in Alzheimer's disease. $J$ Biochem (Tokyo) 1986, 99:1807-1810.

20. Blennow K, de Leon MJ, Zetterberg H: Alzheimer's disease. Lancet 2006 368:387-403.

21. Akiyama H, Barger S, Barnum S, Bradt B, Bauer J, Cole GM, Cooper NR, Eikelenboom P, Emmerling M, Fiebich BL, et al: Inflammation and Alzheimer's disease. Neurobiol Aging 2005, 21:383-421.

22. Wyss-Coray T: Inflammation in Alzheimer disease: driving force, bystander or beneficial response? Nat Med 2006, 12:1005-1015.

23. Christen Y: Oxidative stress and Alzheimer disease1. Am J Clin Nutr 2000, 71:621s-629s.

24. Markesbery WR: Oxidative stress hypothesis in Alzheimer's disease. Free Radic Biol Med 1997, 23:134-147.
25. Sayre LM, Perry G, Smith MA: Oxidative stress and neurotoxicity. Chem Res Toxicol 2007, 21:172-188.

26. Canning DR, McKeon RJ, DeWitt DA, Perry G, Wujek JR, Frederickson RCA, Silver J: [beta]-Amyloid of Alzheimer's disease induces reactive gliosis that inhibits axonal outgrowth. Exp Neurol 1993, 124:289-298.

27. LaFerla FM, Green KN, Oddo S: Intracellular amyloid-[beta] in Alzheimer's disease. Nat Rev Neurosci 2007, 8:499-509.

28. Querfurth HW, LaFerla FM: Mechanisms of disease alzheimer's disease. N Engl J Med 2010, 362:329-344.

29. Gandy S: The role of cerebral amyloid beta accumulation in common forms of Alzheimer disease. J Clin Invest 2005, 115:1121-1129.

30. Kang J, Lemaire HG, Unterbeck A, Salbaum JM, Masters CL, Grzeschik KH, Multhaup G, Beyreuther K, Muller-Hill B: The precursor of Alzheimer's disease amyloid A4 protein resembles a cell-surface receptor. Nature 1987, 325:733-736.

31. Tanzi RE, Bertram L: Twenty years of the alzheimer's disease amyloid hypothesis: A genetic perspective. Cell 2005, 120:545-555.

32. Allinson TM, Parkin ET, Turner AJ, Hooper NM: ADAMs family members as amyloid precursor protein alpha-secretases. J Neurosci Res 2003, 74:342-352.

33. Koike H, Tomioka S, Sorimachi H, Saido TC, Maruyama K, Okuyama A, Fujisawa-Sehara A, Ohno S, Suzuki K, Ishiura S: Membrane-anchored metalloprotease MDC9 has an alpha-secretase activity responsible for processing the amyloid precursor protein. Biochem J 1999, 343(Pt 2):371-375.

34. Asai M, Hattori C, Szabó B, Sasagawa N, Maruyama K, Tanuma Si, Ishiura S: Putative function of ADAM9, ADAM10, and ADAM17 as APP [alpha]secretase. Biochem Biophys Res Commun 2003, 301:231-235.

35. Lammich S, Kojro E, Postina R, Gilbert S, Pfeiffer R, Jasionowski M, Haass C, Fahrenholz F: Constitutive and regulated a-secretase cleavage of Alzheimer's amyloid precursor protein by a disintegrin metalloprotease. Proc Natl Acad Sci USA 1999, 96:3922-3927.

36. Tanabe C, Hotoda N, Sasagawa N, Sehara-Fujisawa A, Maruyama K, Ishiura S: ADAM19 is tightly associated with constitutive Alzheimer's disease APP alpha-secretase in A172 cells. Biochem Biophys Res Commun 2007, 352:111-117.

37. Buxbaum JD, Liu KN, Luo Y, Slack JL, Stocking KL, Peschon JJ, Johnson RS, Castner BJ, Cerretti DP, Black RA: Evidence that tumor necrosis factor alpha converting enzyme is involved in regulated alpha-secretase cleavage of the Alzheimer amyloid protein precursor. J Biol Chem 1998, 273:27765-27767.

38. Jin LW, Ninomiya H, Roch JM, Schubert D, Masliah E, Otero DA, Saitoh T: Peptides containing the RERMS sequence of amyloid beta/A4 protein precursor bind cell surface and promote neurite extension. J Neurosci 1994, 14:5461-5470.

39. Mattson MP: Secreted forms of beta-amyloid precursor protein modulate dendrite outgrowth and calcium responses to glutamate in cultured embryonic hippocampal neurons. J Neurobiol 1994, 25:439-450.

40. Mucke L, Masliah E, Johnson WB, Ruppe MD, Alford M, Rockenstein EM, Forss-Petter S, Pietropaolo M, Mallory M, Abraham CR: Synaptotrophic effects of human amyloid beta protein precursors in the cortex of transgenic mice. Brain Res 1994, 666:151-167.

41. Roch JM, Masliah E, Roch-Levecq AC, Sundsmo MP, Otero DA, Veinbergs I, Saitoh T: Increase of synaptic density and memory retention by a peptide representing the trophic domain of the amyloid beta/A4 protein precursor. Proc Natl Acad Sci USA 1994, 91:7450-7454.

42. Meziane H, Dodart JC, Mathis C, Little S, Clemens J, Paul SM, Ungerer A: Memory-enhancing effects of secreted forms of the $\beta$-amyloid precursor protein in normal and amnestic mice. Proc Natl Acad Sci USA 1998, 95:12683-12688.

43. Mattson MP, Cheng B, Culwell AR, Esch FS, Lieberburg I, Rydel RE: Evidence for excitoprotective and intraneuronal calcium-regulating roles for secreted forms of the beta-amyloid precursor protein. Neuron 1993, 10:243-254.

44. Goodman Y, Mattson MP: Secreted forms of beta-amyloid precursor protein protect hippocampal neurons against amyloid beta-peptideinduced oxidative injury. Exp Neurol 1994, 128:1-12.

45. Mattson MP: Cellular actions of beta-amyloid precursor protein and its soluble and fibrillogenic derivatives. Physiol Rev 1997, 77:1081-1132.

46. Vassar R, Bennett BD, Babu-Khan S, Kahn S, Mendiaz EA, Denis P, Teplow DB, Ross S, Amarante P, Loeloff $R$, et al: \{Beta\}-Secretase cleavage 
of Alzheimer's amyloid precursor protein by the transmembrane aspartic protease BACE. Science 1999, 286:735-741.

47. Sinha S, Anderson JP, Barbour R, Basi GS, Caccavello R, Davis D, Doan M, Dovey HF, Frigon N, Hong J, et al: Purification and cloning of amyloid precursor protein [beta]-secretase from human brain. Nature 1999, 402:537-540.

48. Cai H, Wang Y, McCarthy D, Wen H, Borchelt DR, Price DL, Wong PC: BACE1 is the major beta-secretase for generation of Abeta peptides by neurons. Nat Neurosci 2001, 4:233-234.

49. Luo Y, Bolon B, Kahn S, Bennett BD, Babu-Khan S, Denis P, Fan W, Kha H, Zhang J, Gong Y, et al: Mice deficient in BACE1, the Alzheimer's betasecretase, have normal phenotype and abolished beta-amyloid generation. Nat Neurosci 2001, 4:231-232.

50. Hook V, Toneff T, Bogyo M, Greenbaum D, Medzihradszky KF, Neveu J, Lane W, Hook G, Reisine T: Inhibition of cathepsin B reduces betaamyloid production in regulated secretory vesicles of neuronal chromaffin cells: evidence for cathepsin B as a candidate beta-secretase of Alzheimer's disease. Biol Chem 2005, 386:931-940.

51. Hook V, Kindy M, Hook G: Cysteine protease inhibitors effectively reduce in vivo levels of brain beta-amyloid related to Alzheimer's disease. Biol Chem 2007, 388:247-252

52. Hook VY, Reisine TD: Cysteine proteases are the major beta-secretase in the regulated secretory pathway that provides most of the beta-amyloid in Alzheimer's disease: role of BACE 1 in the constitutive secretory pathway. J Neurosci Res 2003, 74:393-405.

53. Nikolaev A, McLaughlin T, O'Leary DDM, Tessier-Lavigne M: APP binds DR6 to trigger axon pruning and neuron death via distinct caspases. Nature 2009, 457:981-989.

54. Wolfe MS, Xia W, Ostaszewski BL, Diehl TS, Kimberly WT, Selkoe DJ: Two transmembrane aspartates in presenilin-1 required for presenilin endoproteolysis and [gamma]-secretase activity. Nature 1999, 398:513-517.

55. De Strooper B: Alzheimer's disease. Closing in on gamma-secretase. Nature 2000, 405:627-628.

56. De Strooper B: Aph-1, Pen-2, and Nicastrin with Presenilin generate an active gamma-Secretase complex. Neuron 2003, 38:9-12.

57. Haass C, Steiner H: Alzheimer disease gamma-secretase: a complex story of GXGD-type presenilin proteases. Trends Cell Biol 2002, 12:556-562.

58. Kaether C, Haass C, Steiner H: Assembly, trafficking and function of gamma-secretase. Neurodegener Dis 2006, 3:275-283.

59. Sisodia SS, Annaert W, Kim SH, De Strooper B: Gamma-secretase: never more enigmatic. Trends Neurosci 2001, 24:S2-S6.

60. Müller T, Meyer HE, Egensperger R, Marcus K: The amyloid precursor protein intracellular domain (AICD) as modulator of gene expression, apoptosis, and cytoskeletal dynamics-Relevance for Alzheimer's disease. Prog Neurobiol 2008, 85:393-406.

61. Wolfe MS, Haass C: The Role of Presenilins in $\gamma$-Secretase Activity. J Biol Chem 2001, 276:5413-5416

62. Haass C: Take five-BACE and the gamma-secretase quartet conduct Alzheimer's amyloid beta-peptide generation. EMBO J 2004, 23:483-488.

63. Roher AE, Lowenson JD, Clarke S, Woods AS, Cotter RJ, Gowing E, Ball MJ: beta-Amyloid-(1-42) is a major component of cerebrovascular amyloid deposits: implications for the pathology of Alzheimer disease. Proc Natl Acad Sci USA 1993, 90:10836-10840.

64. Iwatsubo T, Odaka A, Suzuki N, Mizusawa $H$, Nukina N, Ihara Y: Visualization of $A$ beta $42(43)$ and $A$ beta 40 in senile plaques with end-specific $A$ beta monoclonals: evidence that an initially deposited species is $\mathrm{A}$ beta 42(43). Neuron 1994, 13:45-53.

65. Turner RS, Suzuki N, Chyung AS, Younkin SG, Lee VM: Amyloids beta40 and beta42 are generated intracellularly in cultured human neurons and their secretion increases with maturation. J Biol Chem 1996, 271:8966-8970.

66. Suzuki N, Cheung TT, Cai XD, Odaka A, Otvos L Jr, Eckman C, Golde TE, Younkin SG: An increased percentage of long amyloid beta protein secreted by familial amyloid beta protein precursor (beta APP717) mutants. Science 1994, 264:1336-1340

67. Cook DG, Forman MS, Sung JC, Leight S, Kolson DL, Iwatsubo T, Lee VM, Doms RW: Alzheimer's A beta(1-42) is generated in the endoplasmic reticulum/intermediate compartment of NT2N cells. Nat Med 1997, 3:1021-1023.
68. Hartmann T, Bieger SC, Bruhl B, Tienari PJ, Ida N, Allsop D, Roberts GW, Masters CL, Dotti CG, Unsicker K, et al: Distinct sites of intracellular production for Alzheimer's disease A beta40/42 amyloid peptides. Nat Med 1997, 3:1016-1020.

69. Koo EH, Squazzo SL: Evidence that production and release of amyloid beta-protein involves the endocytic pathway. J Biol Chem 1994, 269:17386-17389.

70. Chung H, Brazil MI, Soe T, Maxfield FR: Uptake, degradation, and release of fibrillar and soluble forms of Alzheimer's amyloid beta-peptide by microglial cells. J Biol Chem 1999, 274:32301-32308.

71. Nielsen HM, Mulder SD, Belien JA, Musters RJ, Eikelenboom P, Veerhuis R: Astrocytic $A$ beta 1-42 uptake is determined by $A$ beta-aggregation state and the presence of amyloid-associated proteins. Glia 2010, 58:1235-1246.

72. Bell RD, Deane R, Chow N, Long X, Sagare A, Singh I, Streb JW, Guo H, Rubio A, Van NW, et al: SRF and myocardin regulate LRP-mediated amyloid-beta clearance in brain vascular cells. Nat Cell Biol 2009, 11:143-153.

73. Shibata M, Yamada S, Kumar SR, Calero M, Bading J, Frangione B, Holtzman DM, Miller CA, Strickland DK, Ghiso J, et al: Clearance of Alzheimer's amyloid-ss(1-40) peptide from brain by LDL receptor-related protein-1 at the blood-brain barrier. J Clin Invest 2000, 106:1489-1499.

74. Zlokovic BV, Deane R, Sagare AP, Bell RD, Winkler EA: Low-density lipoprotein receptor-related protein-1: a serial clearance homeostatic mechanism controlling Alzheimer's amyloid beta-peptide elimination from the brain. J Neurochem 2010, 115:1077-1089.

75. Tanzi RE, Moir RD, Wagner SL: Clearance of Alzheimer's Abeta peptide: the many roads to perdition. Neuron 2004, 43:605-608.

76. Mackic JB, Stins M, McComb JG, Calero M, Ghiso J, Kim KS, Yan SD, Stern D, Schmidt AM, Frangione B, et al: Human blood-brain barrier receptors for Alzheimer's amyloid-beta 1- 40. Asymmetrical binding, endocytosis, and transcytosis at the apical side of brain microvascular endothelial cell monolayer. J Clin Invest 1998, 102:734-743.

77. Deane R, Du YS, Submamaryan RK, LaRue B, Jovanovic S, Hogg E, Welch D, Manness L, Lin C, Yu J, et al: RAGE mediates amyloid-beta peptide transport across the blood-brain barrier and accumulation in brain. Nat Med 2003, 9:907-913.

78. Qiu WQ, Walsh DM, Ye Z, Vekrellis K, Zhang J, Podlisny MB, Rosner MR, Safavi A, Hersh LB, Selkoe DJ: Insulin-degrading enzyme regulates extracellular levels of amyloid beta-protein by degradation. $J$ Biol Chem 1998, 273:32730-32738

79. Hemming ML, Selkoe DJ: Amyloid beta-protein is degraded by cellular angiotensin-converting enzyme (ACE) and elevated by an ACE inhibitor. J Biol Chem 2005, 280:37644-37650.

80. Hu J, Igarashi A, Kamata M, Nakagawa H: Angiotensin-converting enzyme degrades Alzheimer amyloid beta-peptide (A beta); retards A beta aggregation, deposition, fibril formation; and inhibits cytotoxicity. J Biol Chem 2001, 276:47863-47868.

81. Mueller-Steiner $S$, Zhou $Y$, Arai $H$, Roberson ED, Sun B, Chen J, Wang $X$, Yu G, Esposito L, Mucke L, et al: Antiamyloidogenic and neuroprotective functions of cathepsin B: implications for Alzheimer's disease. Neuron 2006, 51:703-714.

82. Eckman EA, Watson M, Marlow L, Sambamurti K, Eckman CB: Alzheimer's disease beta-amyloid peptide is increased in mice deficient in endothelin-converting enzyme. J Biol Chem 2003, 278:2081-2084.

83. Kim MJ, Chae SS, Koh YH, Lee SK, Jo SA: Glutamate carboxypeptidase II: an amyloid peptide-degrading enzyme with physiological function in the brain. FASEB J 2010, 24:4491-4502.

84. Roher AE, Kasunic TC, Woods AS, Cotter RJ, Ball MJ, Fridman R: Proteolysis of $A$ beta peptide from Alzheimer disease brain by gelatinase $A$. Biochem Biophys Res Commun 1994, 205:1755-1761.

85. Backstrom JR, Lim GP, Cullen MJ, Tokes ZA: Matrix metalloproteinase-9 (MMP-9) is synthesized in neurons of the human hippocampus and is capable of degrading the amyloid-beta peptide (1-40). J Neurosci 1996, 16:7910-7919.

86. Yan P, Hu X, Song H, Yin K, Bateman RJ, Cirrito JR, Xiao Q, Hsu FF, Turk JW, $X \mathrm{U} J$, et al: Matrix metalloproteinase-9 degrades amyloid-beta fibrils in vitro and compact plaques in situ. J Biol Chem 2006, 281:24566-24574.

87. Jacobsen JS, Comery TA, Martone RL, Elokdah H, Crandall DL, Oganesian A, Aschmies S, Kirksey Y, Gonzales C, Xu J, et al: Enhanced clearance of Abeta 
in brain by sustaining the plasmin proteolysis cascade. Proc Natl Acad Sci USA 2008, 105:8754-8759.

88. Tucker HM, Kihiko M, Caldwell JN, Wright S, Kawarabayashi T, Price D, Walker D, Scheff S, McGillis JP, Rydel RE, et al: The plasmin system is induced by and degrades amyloid-beta aggregates. J Neurosci 2000, 20:3937-3946.

89. Iwata N, Tsubuki S, Takaki Y, Watanabe K, Sekiguchi M, Hosoki E, Kawashima-Morishima M, Lee HJ, Hama E, Sekine-Aizawa Y, et al: Identification of the major Abeta1-42-degrading catabolic pathway in brain parenchyma: suppression leads to biochemical and pathological deposition. Nat Med 2000, 6:143-150.

90. Shirotani K, Tsubuki S, Iwata N, Takaki Y, Harigaya W, Maruyama K, KiryuSeo S, Kiyama H, Iwata H, Tomita T, et al: Neprilysin degrades both amyloid beta peptides 1-40 and 1-42 most rapidly and efficiently among thiorphan- and phosphoramidon-sensitive endopeptidases. J Biol Chem 2001, 276:21895-21901.

91. Kurochkin IV, Goto S: Alzheimer's beta-amyloid peptide specifically interacts with and is degraded by insulin degrading enzyme. FEBS Lett 1994, 345:33-37.

92. Iwata N, Tsubuki S, Takaki Y, Shirotani K, Lu B, Gerard NP, Gerard C, Hama E, Lee HJ, Saido TC: Metabolic regulation of brain Abeta by neprilysin. Science 2001, 292:1550-1552.

93. Farris W, Schutz SG, Cirrito JR, Shankar GM, Sun X, George A, Leissring MA, Walsh DM, Qiu WQ, Holtzman DM, et al: Loss of neprilysin function promotes amyloid plaque formation and causes cerebral amyloid angiopathy. Am J Pathol 2007, 171:241-251.

94. Farris W, Mansourian S, Chang Y, Lindsley L, Eckman EA, Frosch MP, Eckman CB, Tanzi RE, Selkoe DJ, Guenette S: Insulin-degrading enzyme regulates the levels of insulin, amyloid beta-protein, and the betaamyloid precursor protein intracellular domain in vivo. Proc Natl Acad Sci USA 2003, 100:4162-4167.

95. Hemming ML, Patterson M, Reske-Nielsen C, Lin L, Isacson O, Selkoe DJ: Reducing amyloid plaque burden via ex vivo gene delivery of an Abetadegrading protease: a novel therapeutic approach to Alzheimer disease. PLoS Med 2007, 4:e262.

96. Leissring MA, Farris W, Chang AY, Walsh DM, Wu X, Sun X, Frosch MP, Selkoe DJ: Enhanced proteolysis of beta-amyloid in APP transgenic mice prevents plaque formation, secondary pathology, and premature death. Neuron 2003, 40:1087-1093.

97. Jiang Q, Lee CY, Mandrekar S, Wilkinson B, Cramer P, Zelcer N, Mann K, Lamb B, Willson TM, Collins JL, et al: ApoE promotes the proteolytic degradation of Abeta. Neuron 2008, 58:681-693.

98. Selkoe DJ: Toward a comprehensive theory for Alzheimer's disease. hypothesis: Alzheimer's disease is caused by the cerebral accumulation and cytotoxicity of amyloid $\beta$ protein. Ann N Y Acad Sci 2000, 924:17-25.

99. Selkoe DJ: Alzheimer's disease: Genes, proteins, and therapy. Physiol Rev 2001, 81:741-766.

100. Selkoe DJ: Alzheimer's disease is a synaptic failure. Science 2002, 298:789-791.

101. Hardy J, Selkoe DJ: The amyloid hypothesis of Alzheimer's disease: progress and problems on the road to therapeutics. Science 2002, 297:353-356.

102. Glenner GG, Wong CW: Alzheimer's disease and Down's syndrome: Sharing of a unique cerebrovascular amyloid fibril protein. Biochem Biophys Res Commun 1984, 122:1131-1135.

103. Masters $C L$, Simms G, Weinman NA, Multhaup G, McDonald BL, Beyreuther K: Amyloid plaque core protein in Alzheimer disease and Down syndrome. Proc Natl Acad Sci USA 1985, 82:4245-4249.

104. Schweber M: A possible unitary genetic hypothesis for Alzheimer's disease and Down syndromea. Ann N Y Acad Sci 1985, 450:223-238.

105. Haass C, Hung AY, Selkoe DJ, Teplow DB: Mutations associated with a locus for familial Alzheimer's disease result in alternative processing of amyloid beta-protein precursor. J Biol Chem 1994, 269:17741-17748.

106. Rogaev El, Sherrington R, Rogaeva E, Levesque G, Ikeda M, Liang Y, Chi H, Lin C, Holman K, Tsuda T, et al: Familial Alzheimer's disease in kindreds with missense mutations in a gene on chromosome 1 related to the Alzheimer's disease type 3 gene. Nature 1995, 376:775-778.

107. Sherrington R, Rogaev E, Liang Y, Rogaeva E, Levesque G, Ikeda M, Chi H, Lin $C, L i G$, Holman $K$, et al: Cloning of a gene bearing missense mutations in early-onset familial Alzheimer's disease. Nature 1995, $375: 754-760$.
108. Citron M, Oltersdorf T, Haass C, McConlogue L, Hung AY, Seubert P, VigoPelfrey C, Lieberburg I, Selkoe DJ: Mutation of the [beta]-amyloid precursor protein in familial Alzheimer's disease increases [beta]-protein production. Nature 1992, 360:672-674.

109. Citron M, Westaway D, Xia W, Carlson G, Diehl T, Levesque G, Johnsonwood K, Lee M, Seubert P, Davis A, et al: Mutant presenilins of Alzheimer's disease increase production of 42-residue amyloid [beta]-protein in both transfected cells and transgenic mice. Nat Med 1997, 3:67-72.

110. Tomita T, Maruyama K, Saido TC, Kume H, Shinozaki K, Tokuhiro S, Capell A, Walter J, Jürgen G, Haass C, et al: The presenilin 2 mutation (N1411) linked to familial Alzheimer disease (Volga German families) increases the secretion of amyloid $\beta$ protein ending at the 42 nd (or $43 \mathrm{rd}$ ) residue. Proc Natl Acad Sci USA 1997, 94:2025-2030.

111. Haass C, Lemere CA, Capell A, Citron M, Seubert P, Schenk D, Lannfelt L, Selkoe DJ: The Swedish mutation causes early-onset Alzheimer's disease by [beta]-secretase cleavage within the secretory pathway. Nat Med 1995, 1:1291-1296.

112. McGowan E, Eriksen J, Hutton M: A decade of modeling Alzheimer's disease in transgenic mice. Trends Genet 2006, 22:281-289.

113. Ashe KH, Zahs KR: Probing the biology of Alzheimer's disease in mice. Neuron 2010, 66:631-645.

114. Duyckaerts C, Potier MC, Delatour B: Alzheimer disease models and human neuropathology: similarities and differences. Acta Neuropathol 2008, 115:5-38.

115. McLean CA, Cherny RA, Fraser FW, Fuller SJ, Smith MJ, Vbeyreuther K, Bush Al, Masters CL: Soluble pool of A amyloid as a determinant of severity of neurodegeneration in Alzheimer's disease. Ann Neurol 1999, 46:860-866.

116. Lue LF, Kuo YM, Roher AE, Brachova L, Shen Y, Sue L, Beach T, Kurth JH, Rydel RE, Rogers J: Soluble amyloid \{beta\} peptide concentration as a predictor of synaptic change in Alzheimer's disease. Am J Pathol 1999, 155:853-862.

117. Walsh DM, Klyubin I, Fadeeva JV, Cullen WK, Anwyl R, Wolfe MS, Rowan MJ, Selkoe DJ: Naturally secreted oligomers of amyloid beta protein potently inhibit hippocampal long-term potentiation in vivo. Nature 2002, 416:535-539.

118. Shankar GM, Bloodgood BL, Townsend M, Walsh DM, Selkoe DJ, Sabatini BL: Natural oligomers of the Alzheimer amyloid-\{beta\} protein induce reversible synapse loss by modulating an NMDA-type glutamate receptor-dependent signaling pathway. J Neurosci 2007, 27:2866-2875.

119. Shankar GM, Li S, Mehta TH, Garcia-Munoz A, Shepardson NE, Smith I, Brett FM, Farrell MA, Rowan MJ, Lemere CA, et al: Amyloid-[beta] protein dimers isolated directly from Alzheimer's brains impair synaptic plasticity and memory. Nat Med 2008, 14:837-842.

120. Walsh DM, Klyubin I, Shankar GM, Townsend M, Fadeeva JV, Betts V, Podlisny MB, Cleary JP, Ashe KH, Rowan MJ, et al: The role of cell-derived oligomers of Abeta in Alzheimer's disease and avenues for therapeutic intervention. Biochem Soc Trans 2005, 33:1087-1090.

121. Lauren J, Gimbel DA, Nygaard HB, Gilbert JW, Strittmatter SM: Cellular prion protein mediates impairment of synaptic plasticity by amyloid- $\beta$ ligomers. Nature 2009, 457:1128-1132.

122. Kessels HW, Nguyen LN, Nabavi S, Malinow R: The prion protein as a receptor for amyloid- $\beta$. Nature 2010, 466:E3-E4.

123. Arriagada PV, Growdon JH, Hedley-Whyte ET, Hyman BT: Neurofibrillary tangles but not senile plaques parallel duration and severity of Alzheimer's disease. Neurology 1992, 42:631-639.

124. Gomez-Isla T, Hollister R, West H, Mui S, Growdon JH, Petersen RC, Parisi JE, Hyman BT: Neuronal loss correlates with but exceeds neurofibrillary tangles in Alzheimer's disease. Ann Neurol 1997, 41:17-24.

125. Mattsson N, Zetterberg H, Hansson O, Andreasen N, Parnetti L, Jonsson M, Herukka SK, van der Flier WM, Blankenstein MA, Ewers M, et al: CSF biomarkers and incipient Alzheimer disease in patients with mild cognitive impairment. JAMA 2009, 302:385-393.

126. Hansson O, Zetterberg H, Buchhave P, Londos E, Blennow K, Minthon L: Association between CSF biomarkers and incipient Alzheimer's disease in patients with mild cognitive impairment: a follow-up study. Lancet Neurol 2006, 5:228-234.

127. Andreasen $N$, Minthon L, Davidsson $P$, Vanmechelen $E$, Vanderstichele $H$, Winblad B, Blennow K: Evaluation of CSF-tau and CSF-A\{beta\}42 as diagnostic markers for Alzheimer disease in clinical practice. Arch Neurol 2001, 58:373-379. 
128. Strozyk D, Blennow K, White LR, Launer LJ: CSF Abeta 42 levels correlate with amyloid-neuropathology in a population-based autopsy study. Neurology 2003, 60:652-656.

129. Shaw LM, Vanderstichele $H$, Knapik-Czajka M, Clark CM, Aisen PS, Petersen RC, Blennow K, Soares H, Simon A, Lewczuk P, et al: Cerebrospinal fluid biomarker signature in Alzheimer's disease neuroimaging initiative subjects. Ann Neurol 2009, 65:403-413.

130. Lambert MP, Barlow AK, Chromy BA, Edwards C, Freed R, Liosatos M, Morgan TE, Rozovsky I, Trommer B, Viola KL, et al: Diffusible, nonfibrillar ligands derived from A beta(1-42) are potent central nervous system neurotoxins. Proc Natl Acad Sci USA 1998, 95:6448-6453.

131. De Felice FG, Velasco PT, Lambert MP, Viola K, Fernandez SJ, Ferreira ST, Klein WL: A beta oligomers induce neuronal oxidative stress through an $\mathrm{N}$-methyl-D-aspartate receptor-dependent mechanism that is blocked by the Alzheimer drug memantine. J Biol Chem 2007, 282:11590-11601.

132. Wang X, Su B, Lee Hg, Li X, Perry G, Smith MA, Zhu X: Impaired balance of mitochondrial fission and fusion in Alzheimer's disease. J Neurosci 2009, 29:9090-9103.

133. Smith MA, Perry G, Richey PL, Sayrec LM, Anderson VE, Beal MF, Kowall N: Oxidative damage in Alzheimer's. Nature 1996, 382:120-121

134. Kim J, Basak JM, Holtzman DM: The role of Apolipoprotein E in Alzheimer's disease. Neuron 2009, 63:287-303.

135. Marchesi VT: An alternative interpretation of the amyloid $A \beta$ hypothesis with regard to the pathogenesis of Alzheimer's disease. Proc Natl Acad Sci USA 2005, 102:9093-9098.

136. Duncan JE, Goldstein LSB: The genetics of axonal transport and axonal transport disorders. PLoS Genet 2006, 2:e124.

137. Trojanowski JQ, Lee VMY: The Alzheimer's brain: Finding out what's broken tells us how to fix it. Am J Pathol 2005, 167:1183-1188.

138. Lee Hg, Zhu X, Castellani RJ, Nunomura A, Perry G, Smith MA: Amyloid- $\beta$ in Alzheimer disease: The null versus the alternate hypotheses. J Pharmacol Exp Ther 2007, 321:823-829.

139. Robakis NK: Are Abeta and its derivatives causative agents or innocent bystanders in AD? Neurodegener Dis 2010, 7:32-37.

140. Robakis NK: Mechanisms of AD neurodegeneration may be independent of Abeta and its derivatives. Neurobiol Aging 2011, 32:372-379.

141. Robinson SR, Bishop GM: Abeta as a bioflocculant: implications for the amyloid hypothesis of Alzheimer's disease. Neurobiol Aging 2002, 23:1051-1072

142. Smith MA, Joseph JA, Perry G: Arson. Tracking the culprit in Alzheimer's disease. Ann N Y Acad Sci 2000, 924:35-38.

143. Williams M: Progress in Alzheimer's disease drug discovery: an update. Curr Opinion Invest Drugs 2008, 10:23-34.

144. Boche D, Denham N, Holmes C, Nicoll JA: Neuropathology after active Abeta42 immunotherapy: implications for Alzheimer's disease pathogenesis. Acta neuropathol 2010, 120:369-384.

145. Johnson SM, Wiseman RL, Sekijima Y, Green NS, Adamski-Werner SL, Kelly JW: Native state kinetic stabilization as a strategy to ameliorate protein misfolding diseases: a focus on the transthyretin amyloidoses. Acc Chem Res 2005, 38:911-921.

146. Tanskanen M, Peuralinna T, Polvikoski T, Notkola IL, Sulkava R, Hardy J, Singleton A, Kiuru-Enari S, Paetau A, Tienari PJ, et al: Senile systemic amyloidosis affects $25 \%$ of the very aged and associates with genetic variation in alpha2-macroglobulin and tau: A population-based autopsy study. Ann Med 2008, 40:232-239.

147. Lie JT, Hammond PI: Pathology of the senescent heart: anatomic observations on 237 autopsy studies of patients 90 to 105 years old. Mayo Clinic Proc 1988, 63:552-564.

148. Connors L, Lim A, Prokaeva T, Roskens VA, Costello CE: Tabulation of human transthyretin (TTR) variants, 2003. Amyloid 2003, 10:160-184.

149. Garzuly F, Vidal R, Wisniewski T, Brittig F, Budka H: Familial meningocerebrovascular amyloidosis, Hungarian type, with mutant transthyretin (TTR Asp18Gly). Neurol 1996, 47:1562-1567.

150. Sekijima Y, Hammarstrom P, Matsumura M, Shimizu Y, Iwata M, Tokuda T, Ikeda S, Kelly JW: Energetic characteristics of the new transthyretin variant A25T may explain its atypical central nervous system pathology. Lab Invest 2003, 83:409-417.

151. Monaco HL: Three-dimensional structure of the transthyretin-retinolbinding protein complex. Clin Chem Lab Med 2002, 40:1229-1236.
152. Andrea TA, Cavalieri RR, Goldfine ID, Jorgensen EC: Binding of thyroid hormones and analogues to the human plasma protein prealbumin. Biochemistry 1980, 19:55-63.

153. Raz A: The interaction of thyroxine with human plasma prealbumin and with the prealbumin-retinol-binding protein complex. J Biol Chem 1969, 244:3230-3237.

154. Episkopou V, Maeda S, Nishiguchi S, Shimada K, Gaitanaris GA, Gottesman ME, Robertson EJ: Disruption of the transthyretin gene results in mice with depressed levels of plasma retinol and thyroid-hormone. Proc Natl Acad Sci USA 1993, 90:2375-2379.

155. Palha JA, Hays MT, Morreale de EG, Episkopou V, Gottesman ME, Saraiva MJ: Transthyretin is not essential for thyroxine to reach the brain and other tissues in transthyretin-null mice. Am J Physiol 1997, 272:E485-E493.

156. Wei S, Episkopou V, Piantedosi R, Maeda S, Shimada K, Gottesman ME, Blaner WS: Studies on the metabolism of retinol and retinol-binding protein in transthyretin-deficient mice produced by homologous recombination. J Biol Chem 1995, 270:866-870.

157. Sousa JC, Grandela C, Fernandez-Ruiz J, de Miguel R, de Sousa L, Magalhaes Al, Saraiva MJ, Sousa N, Palha JA: Transthyretin is involved in depression-like behaviour and exploratory activity. J Neurochem 2004, 88:1052-1058.

158. Buxbaum JN, Ye Z, Reixach N, Friske L, Levy C, Das P, Golde T, Masliah E, Roberts AR, Bartfai T: Transthyretin protects Alzheimer's mice from the behavioral and biochemical effects of A beta toxicity. Proc Natl Acad Sci USA 2008, 105:2681-2686.

159. Nunes AF, Saraiva MJ, Sousa MM: Transthyretin knockouts are a new mouse model for increased neuropeptide Y. FASEB J 2006, 20:166-168.

160. Fleming CE, Saraiva MJ, Sousa MM: Transthyretin enhances nerve regeneration. J Neurochem 2007, 103:831-839.

161. Richardson SJ, Lemkine GF, Alfama G, Hassani Z, Demeneix BA: Cell division and apoptosis in the adult neural stem cell niche are differentially affected in transthyretin null mice. Neurosci Lett 2007, 421:234-238.

162. Myron Johnson A: Clinical indications for plasma protein assays: transthyretin (prealbumin) in inflammation and malnutrition: International Federation of Clinical Chemistry and Laboratory Medicine (IFCC): IFCC Scientific Division Committee on Plasma Proteins (C-PP). Clin Chem Lab Med 2007, 45:419-426.

163. Kozak KR, Su F, Whitelegge JP, Faull K, Reddy S, Farias-Eisner R: Characterization of serum biomarkers for detection of early stage ovarian cancer. Proteomics 2005, 5:4589-4596.

164. Liu L, Liu J, Dai S, Wang X, Wu S, Wang J, Huang L, Xiao X, He D: Reduced transthyretin expression in sera of lung cancer. Cancer Sci 2007, 98:1617-1624.

165. Herbert J, Wilcox JN, Pham KT, Fremeau RT Jr, Zeviani M, Dwork A, Soprano DR, Makover A, Goodman DS, Zimmerman EA, et al: Transthyretin: A choroid plexus-specific transport protein in human brain: The $1986 \mathrm{~S}$. Weir Mitchell Award. Neurology 1986, 36:900.

166. Getz RK, Kennedy BG, Mangini NJ: Transthyretin localization in cultured and native human retinal pigment epithelium. Exp Eye Res 1999, 68:629-636.

167. Schwarzman AL, Goldgaber D: Interaction of transthyretin with amyloid beta-protein: binding and inhibition of amyloid formation. Ciba Found Symp 1996, 199:146-160.

168. Stein TD, Anders NJ, Decarli C, Chan SL, Mattson MP, Johnson JA: Neutralization of transthyretin reverses the neuroprotective effects of secreted amyloid precursor protein (APP) in APP(Sw) mice resulting in tau phosphorylation and loss of hippocampal neurons: Support for the amyloid hypothesis. J Neurosci 2004, 24:7707-7717.

169. Li X, Masliah E, Reixach N, Buxbaum JN: Neuronal production of transthyretin in human and murine Alzheimer's disease: is it protective? J Neurosci 2011, 31:12483-12490.

170. Carro E, Trejo JL, Gerber A, Loetscher H, Torrado J, Metzger F, TorresAleman I: Therapeutic actions of insulin-like growth factor I on APP/PS2 mice with severe brain amyloidosis. Neurobiol Aging 2006, 27:1250-1257.

171. Stein TD, Johnson JA: Lack of neurodegeneration in transgenic mice overexpressing mutant amyloid precursor protein is associated with increased levels of transthyretin and the activation of cell survival pathways. J Neurosci 2002, 22:7380-7388.

172. Hovatta I, Schadt EE, Libiger O, Schork NJ, Lockhart DJ, Barlow C, Zapala MA, Broide RS: DNA variation and brain region-specific expression 
profiles exhibit different relationships between inbred mouse strains: implications for eQTL mapping studies. Genome Biol 2007, 8:R25.

173. Dickson PW, Aldred AR, Marley PD, Bannister D, Schreiber G: Rat choroid plexus specializes in the synthesis and the secretion of transthyretin (prealbumin). Regulation of transthyretin synthesis in choroid plexus is independent from that in liver. J Biol Chem 1986, 261:3475-3478.

174. Murakami T, Ohsawa Y, Sunada Y: The transthyretin gene is expressed in human and rodent dorsal root ganglia. Neurosci Lett 2008, 436:335-339.

175. Sousa MM, Saraiva MJ: Transthyretin is not expressed by dorsal root ganglia cells. Exp Neurol 2008, 214:362-365.

176. Murakami T, Ohsawa Y, Zhenghua L, Yamamura Ki, Sunada Y: The transthyretin gene is expressed in Schwann cells of peripheral nerves. Brain Res 2010, 1348:222-225.

177. Eikelenboom P, Stam FC: An immunohistochemical study on cerebral vascular and senile plaque amyloid in Alzheimer's dementia. Virchows Arch B Cell Pathol Ind Mol Pathol 1984, 47:17-25.

178. Shirahama T, Skinner M, Westermark P, Rubinow A, Cohen AS, Brun A, Kemper TL: Senile cerebral amyloid. Prealbumin as a common constituent in the neuritic plaque, in the neurofibrillary tangle, and in the microangiopathic lesion. Am J Pathol 1982, 107:41-50.

179. Ng L, Bernard A, Lau C, Overly CC, Dong HW, Kuan C, Pathak S, Sunkin SM, Dang C, Bohland JW, et al: An anatomic gene expression atlas of the adult mouse brain. Nat Neurosci 2009, 12:356-362.

180. Serot JM, Christmann D, Dubost T, Couturier M: Cerebrospinal fluid transthyretin: Aging and late onset Alzheimer's disease. I Neurol Neurosurg Psychiatry 1997, 63:506-508.

181. Riisoen H: Reduced prealbumin (transthyretin) in CSF of severely demented patients with Alzheimer's disease. Acta Neurol Scand 1988, 78:455-459

182. Hansson SF, Andreasson U, Wall M, Skoog I, Andreasen N, Wallin A, Zetterberg $\mathrm{H}$, Blennow K: Reduced levels of amyloid-beta-binding proteins in cerebrospinal fluid from Alzheimer's disease patients. $J$ Alzheimers Dis 2009, 16:389-397.

183. Gloeckner SF, Meyne F, Wagner F, Heinemann U, Krasnianski A, Meissner B, Zerr I: Quantitative analysis of transthyretin, tau and amyloid-beta in patients with dementia. J Alzheimers Dis 2008, 14:17-25.

184. Castano EM, Roher AE, Esh CL, Kokjohn TA, Beach T: Comparative proteomics of cerebrospinal fluid in neuropathologically-confirmed Alzheimer's disease and non-demented elderly subjects. Neurol Res 2006, 28:155-163.

185. Schultz K, Nilsson K, Nielsen JE, Lindquist SG, Hjermind LE, Andersen BB, Wallin A, Nilsson C, Petersen A: Transthyretin as a potential CSF biomarker for Alzheimer's disease and dementia with Lewy bodies: effects of treatment with cholinesterase inhibitors. Eur J Neurol 2010, 17:456-460.

186. Cuenco KT, Friedland R, Baldwin CT, Guo J, Vardarajan B, Lunetta KL, Cupples LA, Green RC, Decarli C, Farrer LA: Association of TTR polymorphisms with hippocampal atrophy in Alzheimer disease families. Neurobiol Aging 2011, 32:249-256.

187. Palha JA, Moreira P, Wisniewski T, Frangione B, Saraiva MJ: Transthyretin gene in Alzheimer's disease patients. Neurosci Lett 1996, 204:212-214.

188. Hatterer JA, Herbert J, Hidaka C, Roose SP, Gorman JM: CSF transthyretin in patients with depression. Am J Psychiatry 1993, 150:813-815.

189. Schultz K, Traskman-Bendz L, Petersen A: Transthyretin in cerebrospinal fluid from suicide attempters. J Affect Disord 2008, 109:205-208.

190. Brettschneider J, Lehmensiek V, Mogel H, Pfeifle M, Dorst J, Hendrich C, Ludolph AC, Tumani H: Proteome analysis reveals candidate markers of disease progression in amyotrophic lateral sclerosis (ALS). Neurosci Lett 2010, 468:23-27.

191. Tsuzuki K, Fukatsu R, Yamaguchi H, Tateno M, Imai K, Fujii N, Yamauchi T: Transthyretin binds amyloid [beta] peptides, A[beta]1-42 and A[beta]140 to form complex in the autopsied human kidney - possible role of transthyretin for A[beta] sequestration. Neurosci Lett 2000, 281:171-174.

192. Askanas V, Engel WK, Alvarez RB, Frangione B, Ghiso J, Vidal R: Inclusion body myositis, muscle blood vessel and cardiac amyloidosis, and transthyretin Val122lle allele. Annals of Neurol 2000, 47:544-549.

193. Vatassery GT, Quach HT, Smith WE, Benson BA, Eckfeldt JH: A sensitive assay of transthyretin (prealbumin) in human cerebrospinal fluid in nanogram amounts by ELISA. Clin Chim Acta 1991, 197:19-25.
194. Price JM, Chi X, Hellermann G, Sutton ET: Physiological levels of betaamyloid induce cerebral vessel dysfunction and reduce endothelial nitric oxide production. Neurol Res 2001, 23:506-512.

195. Hulstaert F, Blennow K, Ivanoiu A, Schoonderwaldt HC, Riemenschneider M, Deyn PPD, Bancher C, Cras P, Wiltfang J, Mehta PD, et al: Improved discrimination of AD patients using \{beta\}-amyloid(1-42) and tau levels in CSF. Neurology 1999, 52:1555.

196. Link CD: Expression of human beta-amyloid peptide in transgenic Caenorhabditis elegans. Proc Natl Acad Sci USA 1995, 92:9368-9372.

197. Wu ZL, Ciallella JR, Flood DG, O'kane TM, Bozyczko-Coyne D, Savage MJ: Comparative analysis of cortical gene expression in mouse models of Alzheimer's disease. Neurobiol Aging 2006, 27:377-386.

198. Choi SH, Leight SN, Lee VM, Li T, Wong PC, Johnson JA, Saraiva MJ, Sisodia SS: Accelerated Abeta deposition in APPswe/PS1deltaE9 mice with hemizygous deletions of TTR (transthyretin). J Neurosci 2007, 27:7006-7010.

199. Wati H, Kawarabayashi T, Matsubara E, Kasai A, Hirasawa T, Kubota T, Harigaya Y, Shoji M, Maeda S: Transthyretin accelerates vascular Abeta deposition in a mouse model of Alzheimer's disease. Brain Pathol 2009, 19:48-57.

200. Doggui S, Brouillette J, Chabot JG, Farso M, Quirion R: Possible involvement of transthyretin in hippocampal beta-amyloid burden and learning behaviors in a mouse model of Alzheimer's disease (TgCRND8). Neurodegener Dis 2010, 7:88-95.

201. Teplow DB: Preparation of amyloid beta-protein for structural and functional studies. Methods Enzymol 2006, 413:20-33.

202. Schwarzman AL, Tsiper M, Wente H, Wang A, Vitek MP, Vasiliev V, Goldgaber D: Amyloidogenic and anti-amyloidogenic properties of recombinant transthyretin variants. Amyloid 2004, 11:1-9.

203. Costa R, Goncalves A, Saralva MJ, Cardoso I: Transthyretin binding to ABeta peptide - Impact on A-Beta fibrillogenesis and toxicity. FEBS Lett 2008, 582:936-942.

204. Giunta S, Valli MB, Galeazzi R, Fattoretti P, Corder EH, Galeazzi L: Transthyretin inhibition of amyloid beta aggregation and toxicity. Clin Biochem 2005, 38:1112-1119.

205. Liu L, Murphy RM: Kinetics of inhibition of beta-amyloid aggregation by transthyretin. Biochemistry (Mosc) 2006, 45:15702-15709.

206. Du J, Murphy RM: Characterization of the interaction of beta-amyloid with transthyretin monomers and tetramers. Biochemistry (Mosc) 2010, 49:8276-8289.

207. Mazur-Kolecka Bcdae, Frackowiak J, Wisniewski HM: Apolipoproteins E3 and E4 induce, and transthyretin prevents accumulation of the Alzheimer's [beta]-amyloid peptide in cultured vascular smooth muscle cells. Brain Res 1995, 698:217-222.

208. Costa R, Ferreira-da-Silva F, Saraiva MJ, Cardoso I: Transthyretin protects against A-beta peptide toxicity by proteolytic cleavage of the peptide: a mechanism sensitive to the Kunitz protease inhibitor. Plos ONE 2008, 3: e2899.

209. Matsuda S, Giliberto L, Matsuda Y, Davies P, McGowan E, Pickford F, Ghiso J, Frangione B, D'Adamio L: The familial dementia BRI2 gene binds the Alzheimer gene amyloid-beta precursor protein and inhibits amyloidbeta production. J Biol Chem 2005, 280:28912-28916.

210. Matsuoka Y, Saito M, LaFrancois J, Saito M, Gaynor K, Olm V, Wang L, Casey E, Lu Y, Shiratori C, et al: Novel therapeutic approach for the treatment of Alzheimer's disease by peripheral administration of agents with an affinity to beta-amyloid. J Neurosci 2003, 23:29-33.

211. Deane R, Bell RD, Sagare A, Zlokovic BV: Clearance of amyloid-beta peptide across the blood-brain barrier: implication for therapies in Alzheimer's disease. CNS Neurol Disord Drug Targets 2009, 8:16-30.

212. Balch WE, Morimoto RI, Dillin A, Kelly JW: Adapting proteostasis for disease intervention. Science 2008, 319:916-919.

213. Mi W, Pawlik M, Sastre M, Jung SS, Radvinsky DS, Klein AM, Sommer J, Schmidt SD, Nixon RA, Mathews PM, et al: Cystatin C inhibits amyloid-beta deposition in Alzheimer's disease mouse models. Nat Genet 2007, 39:1440-1442.

214. Kaeser SA, Herzig MC, Coomaraswamy J, Kilger E, Selenica ML, Winkler DT, Staufenbiel M, Levy E, Grubb A, Jucker M: Cystatin C modulates cerebral beta-amyloidosis. Nat Genet 2007, 39:1437-1439. 
215. Kim J, Miller VM, Levites Y, Jansen-West K, Zwizinski CW, Moore BD, Troendle FJ, Bann M, Verbeeck C, Price RW, et al: BRI2 (ITM2b) Inhibits Abeta Deposition in Vivo. J Neurosci 2008, 28:6030-6036.

216. Vidal R, Frangione B, Rostagno A, Mead S, Revesz T, Plant G, Ghiso J: A stop-codon mutation in the BRI gene associated with familial British dementia. Nature 1999, 399:776-781.

217. Ray I, Chauhan A, Wegiel J, Chauhan VPS: Gelsolin inhibits the fibrillization of amyloid beta-protein, and also defibrillizes its preformed fibrils. Brain Res 2000, 853:344-351.

218. Chauhan V, Ji L, Chauhan A: Anti-amyloidogenic, anti-oxidant and antiapoptotic role of gelsolin in Alzheimer's disease. Biogerontology 2008, 9:381-389.

219. Bastianetto S, Brouillette J, Quirion R: Neuroprotective Effects of Natural Products: Interaction with Intracellular Kinases, Amyloid Peptides and a Possible Role for Transthyretin. Neurochem Res 2007, 32:1720-1725.

220. Brouillette J, Quirion R: Transthyretin: a key gene involved in the maintenance of memory capacities during aging. Neurobiol Aging 2008, 29:1721-1732.

221. Liz MA, Gomes CM, Saraiva MJ, Sousa MM: ApoA-I cleaved by transthyretin has reduced ability to promote cholesterol efflux and increased amyloidogenicity. J Lipid Res 2007, 48:2385-2395.

222. Buxbaum JN, Reixach N: Transthyretin: the servant of many masters. Cell Mol Life Sci 2009, 66:3095-3101.

223. Stein TD, Johnson JA: Genetic programming by the proteolytic fragments of the amyloid precursor protein: somewhere between confusion and clarity. Rev Neurosci 2003, 14:317-341.

224. Cao X, Südhof TC: Dissection of Amyloid- $\beta$ precursor protein-dependent transcriptional transactivation. J Biol Chem 2004, 279:24601-24611.

225. Pardossi-Piquard R, Petit A, Kawarai T, Sunyach C, Alves da Costa C Vincent B, Ring S, D'Adamio L, Shen J, Mnller U, et al: PresenilinDependent Transcriptional Control of the A[beta]-Degrading Enzyme Neprilysin by Intracellular Domains of [beta]APP and APLP. Neuron 2005, 46:541-554.

226. von Rotz RC, Kohli BM, Bosset J, Meier M, Suzuki T, Nitsch RM, Konietzko U: The APP intracellular domain forms nuclear multiprotein complexes and regulates the transcription of its own precursor. J Cell Sci 2004, 117:4435-4448.

227. Cao X, Südhof TC: A transcriptively active complex of APP with Fe65 and histone acetyltransferase Tip60. Science 2001, 293:115-120.

228. Liu Q, Zerbinatti CV, Zhang J, Hoe HS, Wang B, Cole SL, Herz J, Muglia L, $\mathrm{Bu}$ G: Amyloid precursor protein regulates brain apolipoprotein $\mathrm{E}$ and cholesterol metabolism through lipoprotein receptor LRP1. Neuron 2007, 56:66-78.

229. Zhang YW, Wang R, Liu Q, Zhang H, Liao FF, Xu H: Presenilin/Y-secretasedependent processing of $\beta$-amyloid precursor protein regulates EGF receptor expression. Proc Natl Acad Sci USA 2007, 104:10613-10618.

230. Li H, Wang B, Wang Z, Guo Q, Tabuchi K, Hammer RE, Südhof TC, Zheng H: Soluble amyloid precursor protein (APP) regulates transthyretin and Klotho gene expression without rescuing the essential function of APP. Proc Natl Acad Sci USA 2010, 107:17362-17367.

231. Lazarov O, Robinson J, Tang YP, Hairston IS, Korade-Mirnics Z, Lee VMY, Hersh LB, Sapolsky RM, Mirnics K, Sisodia SS: Environmental enrichment reduces a[beta] levels and amyloid deposition in transgenic mice. Cell 2005, 120:701-713.

232. Watanabe CM, Wolffram S, Ader P, Rimbach G, Packer L, Maguire JJ, Schultz PG, Gohil K: The in vivo neuromodulatory effects of the herbal medicine ginkgo biloba. Proc Natl Acad Sci USA 2001, 98:6577-6580.

233. Puskás LG, Kitajka K, Nyakas C, Barcelo-Coblijn G, Farkas T: Short-term administration of omega 3 fatty acids from fish oil results in increased transthyretin transcription in old rat hippocampus. Proc Natl Acad Sci USA 2003, 100:1580-1585.

234. Kitajka K, Sinclair AJ, Weisinger RS, Weisinger HS, Mathai M, Jayasooriya AP, Halver JE, Puskas LG: Effects of dietary omega-3 polyunsaturated fatty acids on brain gene expression. Proc Natl Acad Sci USA 2004, 101:10931-10936.

235. Augustin S, Rimbach G, Augustin K, Schliebs R, Wolffram S, Cermak R: Effect of a short- and long-term treatment with Ginkgo biloba extract on amyloid precursor protein levels in a transgenic mouse model relevant to Alzheimer's disease. Arch Biochem Biophys 2009, 481:177-182.

236. Stackman RW, Eckenstein F, Frei B, Kulhanek D, Nowlin J, Quinn JF: Prevention of age-related spatial memory deficits in a transgenic mouse model of Alzheimer's disease by chronic Ginkgo biloba treatment. Exp Neurol 2003, 184:510-520.

237. DeKosky ST, Williamson JD, Fitzpatrick AL, Kronmal RA, Ives DG, Saxton JA, Lopez OL, Burke G, Carlson MC, Fried LP, et al: Ginkgo biloba for prevention of dementia: a randomized controlled trial. JAMA 2008, 300:2253-2262.

238. Hirko AC, Meyer EM, King MA, Hughes JA: Peripheral transgene expression of plasma gelsolin reduces amyloid in transgenic mouse models of Alzheimer's disease. Mol Ther 2007, 15:1623-1629.

239. Kinghorn KJ, Crowther DC, Sharp LK, Nerelius C, Davis RL, Chang HT, Green C, Gubb DC, Johansson J, Lomas DA: Neuroserpin binds Abeta and is a neuroprotective component of amyloid plaques in Alzheimer disease. J Biol Chem 2006, 281:29268-29277.

doi:10.1186/1750-1326-6-79

Cite this article as: Li and Buxbaum: Transthyretin and the brain revisited: Is neuronal synthesis of transthyretin protective in Alzheimer's disease? Molecular Neurodegeneration 2011 6:79.

\section{Submit your next manuscript to BioMed Central and take full advantage of:}

- Convenient online submission

- Thorough peer review

- No space constraints or color figure charges

- Immediate publication on acceptance

- Inclusion in PubMed, CAS, Scopus and Google Scholar

- Research which is freely available for redistribution 